\title{
Connessioni di genere e esperienze di video-grafica
}

\author{
IgorTodisco \\ Ornella Zerlenga
}

\section{Abstract}

L'intervento proposto riguarda un'esperienza didattica di sperimentazione video-grafica condotta allinterno del più generale campo della scienza della rappresentazione. II contributo connette le discipline della rappresentazione ai contemporanei linguaggi multimediali della video-grafica ed esplora l'impianto pluridisciplinare del video-clip quale comunicazione audio-visiva di durata breve.

Nello specifico, l'esperienza didattica sperimentale (condotta all'interno del corso di laurea magistrale in Design per l'Innovazione, Dipartimento di Architettura e Disegno industriale, Università degli studi della Campania 'Luigi Vanvitelli') consiste nella progettazione di un video-cortometraggio, presentato al pubblico come evento culturale al PAN, Palazzo delle Arti di Napoli, a luglio 2019. Ispirato ai contributi artistici di Rita Esposito, II fiume di rose, e di Chiara Tortorelli, II gesto sacro, il progetto video-grafico costruisce la narrazione di una storia emozionale che induce a riflettere sulle questioni di genere e, più in generale, sulla diversità. Realizzato con la direzione artistica del fotografo professionista Igor Todisco, il video della durata di poco più di tre minuti, si avvale dei linguaggi e delle tecniche di messa in opera delle scienze grafiche e, più in generale, del disegno per configurare scene, abiti e testi, interagendo con altre forme di comunicazione come l'audio e la danza.

Parole chiave

video-grafica; tipografia cinetica; modellazione digitale; disegno; disegno grafico.

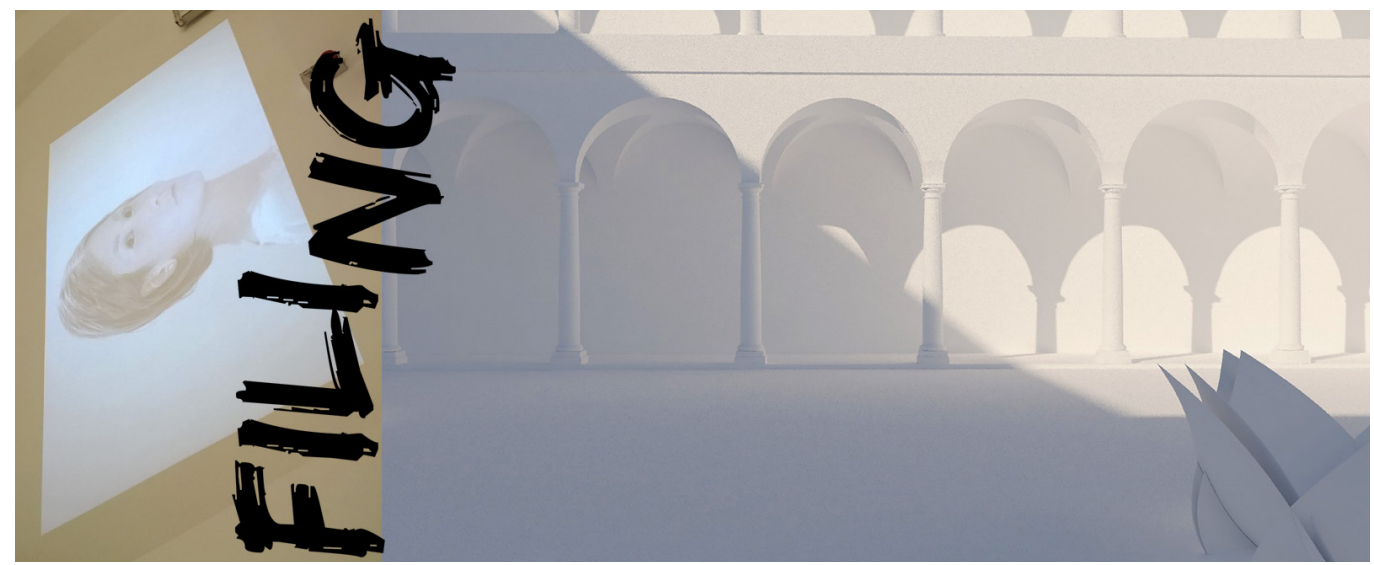




\section{Introduzione}

Riflettendo sulle relazioni fra disegno e innumerevoli forme di arte e scienza, questo contributo connette le discipline della rappresentazione ai linguaggi multimediali contemporanei della video-grafica. Esplorando l'impianto pluridisciplinare del videoclip quale comunicazione audiovisiva di durata breve, il cortometraggio FILIng (coordinato da chi scrive ed esito della didattica del Corso di Laurea magistrale in Design per l'Innovazione, Dipartimento di Architettura e Disegno industriale, Università degli studi della Campania 'Luigi Vanvitelli', A.A. 2018-2019) propone una trama narrativa che, attraverso fili infiniti, connette punti di vista plurimi sulla diversità di genere, tema oggi ancora drammaticamente attuale, rappresentandone matrici fondative e culturali. Quale risposta emozionale, FILIng delinea un intreccio di significati e definisce una visione di ricerca che in modo trasversale integra disegno, multimedialità e comunicazione, annodando e tessendo relazioni fra nuovi e rinnovati saperi. (OZ).

Fig. I. Le opere artistiche

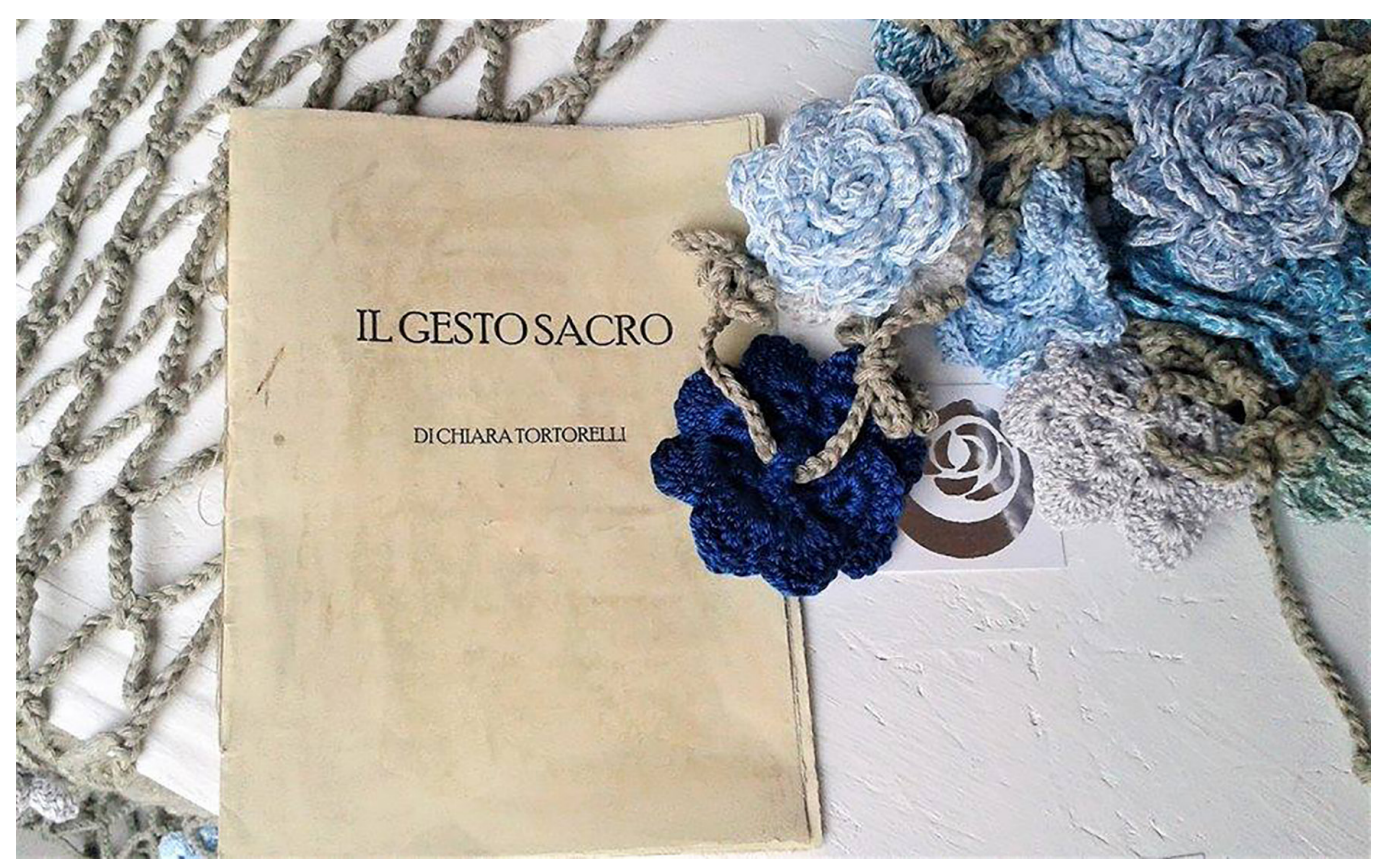

\section{Questioni di genere}

Le opere artistiche di Rita Esposito (1968) e Chiara Tortorelli (1970) sono state di fondamentale importanza per la concezione e narrazione del messaggio contenuto nel videoclip FILIng (fig. I). II fiume di rose nasce da un'idea originale di Rita Esposito [Esposito 20 I6]. Presentata al pubblico a Napoli il 27 settembre 20 I 8, l'opera è una live-performance dinamica, una rete tessuta a uncinetto in 9 mesi e lunga 33 metri. Celebrando la donna, l'opera richiama i concetti di sorellanza, accoglienza e condivisione. Durante le numerose tappe di live-performance su territorio nazionale (fig. 2), l'artista crea un manufatto artistico collettivo formato da una rete su cui molteplici mani di donne, e poi anche di uomini, hanno annodato rose di colore diverso realizzate all'uncinetto. Nel suo divenire, l'opera acquisisce un intenso valore simbolico trasformando un filato in un luogo di pensiero creativo e di amore. L'opera diventa architettura e metafora della vita stessa evocando condivisione e solidarietà originaria, che trovano nell'epifania del femminile un sentimento di mondo caratterizzato dalla rete degli affetti e della cura reciproca. La live-performance si è conclusa al PAN, Palazzo delle Arti di Napoli, il 2I luglio 2019 dove, per l'occasione, è stato proiettato al pubblico il videoclip FILIng. 
La lettura estemporanea del testo II gesto sacro di Chiara Tortorelli, un componimento breve e coinvolgente, ha accompagnato la live-performance di Rita Esposito. Nato da ricordi infantili, l'opera richiama alla memoria l'attività silenziosa delle donne di tessere in circolo sentendosi unite. Evocando luoghi, tradizioni e gesti sacri, Tortorelli rinvia al potere della Grande Madre nel tessere e connettere pace e armonia.

I riferimenti culturali delle opere artistiche rimandano alle antiche società matriarcali dove le donne avevano ruoli significativi e gli insediamenti erano pacifici perché la guerra era pressoché sconosciuta. Questa civiltà delle donne era egualitaria e credeva nella Dea Madre (fig. 3). Johann Jacob Bachofen ( 18 I5- I 887) fu il primo a introdurre nel I86I l'idea di un passato matriarcale dell'umanità [Schiavoni 1988] così come il filosofo ed economista Friedrich Engels (I820-1895) nel I884 ne spiegò la fine con la nascita della proprietà privata [Codino 20 I9]. Congressi mondiali su "Studi matriarcali" (Lussembrugo 2003, Texas 2005) e ricerche recenti a cura di Momolina Marconi (19|2-2006) [Stornaiuolo 20 I5] e delle antropologhe Marija Gimbutas ( I92 I-1994) [Gimbutas 2008] e Heide Göttner-Abendroth ( I94 I) [Göttner-Abendroth 2013] dimostrano che la civiltà megalitica del Neolitico era incentrata sulle donne e che questo modello non corrispondesse alla dominazione opposta di un sesso sull'altro ma a una cultura di equilibrio dei ruoli. L'economia era basata su un'agricoltura di autosostentamento, sulla cultura del dono invece dello scambio per assicurare il riequilibrio sociale e, soprattutto, sulla democrazia partecipativa a base assembleare e continua ricerca del consenso. I bambini vivevano nei villaggi materni accuditi da madri e parenti materni (donne e uomini) e prendevano il nome materno ereditandone i beni. La paternità era sociale, retaggio forse della non consapevolezza maschile nel processo di fecondazione.

Secondo Gimbutas, dal 4.500 al 3.000 a.C. popoli guerrieri provenienti dal Volga e credenti in divinità maschili dilagarono in Europa e nel vicino Oriente e, lentamente, con la forza fisica e con l'appoggio dei maschi delle popolazioni matriarcali, soggiogarono le società matriarcali. Secondo l'antropologa Luciana Percovich (1947) [Percovich 2007], questi pretesero che le donne si trasferissero nei loro villaggi affinché potessero avere sicurezza della paternità e trasmettere i beni per linea maschile. La guerra diventò una forma di economia e la forza maschile molto più importante di un tempo. Le donne furono segregate e sottomesse. La dea madre diventò un ricordo lontano, un'utopia sociale tant'è che nella Grecia classica Zeus superò la Natura partorendo la figlia Atena dalla testa [Capone 20 I7] (fig. 4). (OZ).

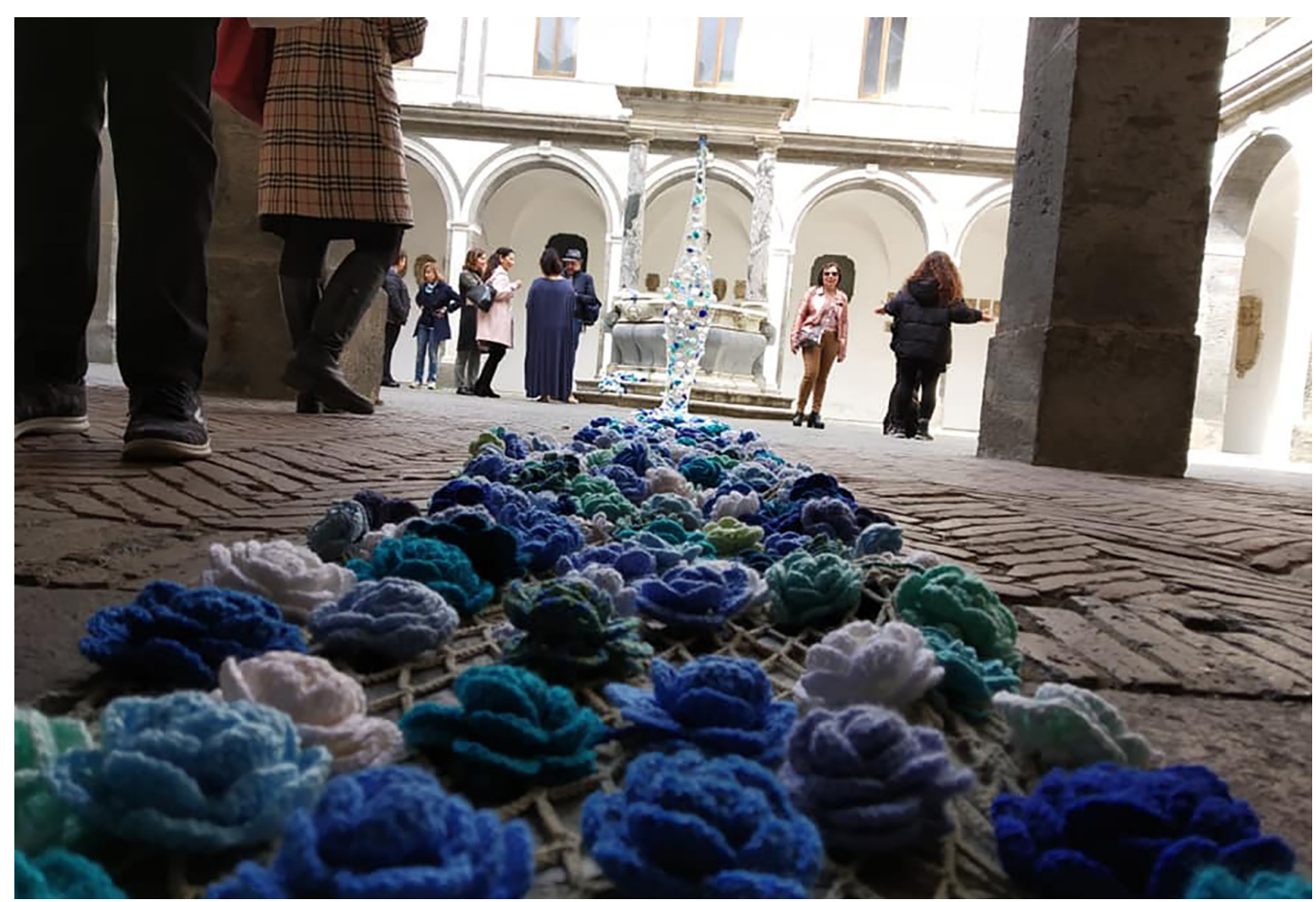


Fig. 3. Dea Madre (Turchia, Museo di Ankara).

Fig. 4. La nascita di Atena dalla testa di Zeus (Kylix attico a figure nere, 550 a.C., British Museum, Londra).
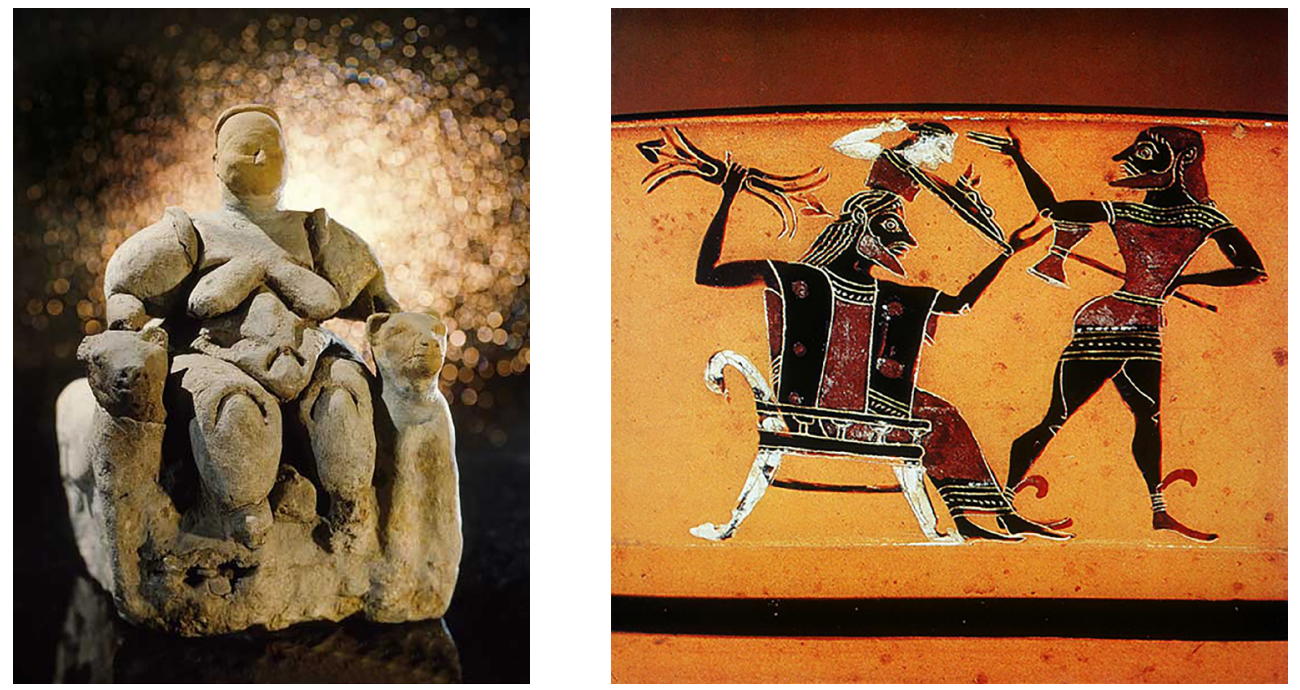

\section{Forme plurime di rappresentazione}

Nel 1963 si svolse a Wuppertal in Germania la prima esposizione di video-arte [Lischi 20 I5]. Pioniere di questa nuova forma di comunicazione fu Paik June Nam (1932-2006). La mostra, intitolata Exposition of music electronic television, fu allestita in un appartamento e Paik creò una performance mescolando musica elettronica a numerose immagini elettroniche ottenute distorcendo i programmi televisivi durante la trasmissione [Bernardelli 2003] (figg. 5, 6). Grazie alle successive tecnologie di registrazione e riproduzione di segnali video-audio attraverso nastri magnetici, i videotape immisero sul mercato nuove opportunità di comunicazione e nel 1968 al motto diVT is not TV il videoartista Paul Ryan sancì la differenza tecnologica e sociale fra videotape e television [Ryan 1988]. Questa nuova tecnologia ebbe un forte impatto nel mondo artistico. La dimensione dinamica del video superava immagine statica e fotografia e, sfruttando le potenzialità di comunicazione dello schermo televisivo ('tele', dal greco 'lontano'), sanciva la straordinaria capacità di trasportare ovunque un messaggio dematerializzato.

La video-proiezione si affermò sulla scena come una nuova 'forma simbolica' e dalla fine degli anni Ottanta del secolo scorso l'orientamento dei linguaggi visivi diventò sempre più multimediale. L'integrazione di scrittura, suono, immagine visiva e animazione comportò la nascita di prodotti nuovi nell'ambito del disegno grafico e un modo diverso di guardare all'arte. L'invenzione di un mezzo nuovo per veicolare il prodotto (non più la 'carta' ma il 'video') integrò sia l'arte 'dello spazio' (disegno) che 'del tempo' (suono e animazione) [Galbiati 2005]. Questi prodotti multimediali consentirono di progettare narrazioni in cui spazio e tempo si connettevano secondo un'estetica della velocità e logiche discontinue, interstiziali, brevi. Nel volume II linguaggio dei nuovi media, Lev Manovich (1960) figurò una 'società dello schermo' dominata da media digitali in cui la comunicazione multimediale svolgeva un ruolo fondamentale [Busnelli et al. $20 \mathrm{ll}$ l]. Questa trasformazione di linguaggio originò sistemi comunicativi ibridi, costituiti da flussi di scritture dove immagini statiche e in movimento si mescolavano senza discontinuità e limiti temporali. La nuova era del progetto caratterizzata da immagini dinamiche coinvolge oltremodo il senso della visione avvalorando il pensiero di Arnheim: "Il movimento è il più forte richiamo visivo dell'attenzione" [Arheim I98I, p. 303]. In questa rivoluzione tecnologica e culturale della videoarte si inserisce la grafica. II canale creativo si sposta dalla carta allo schermo. La videografica si afferma come immagine di sintesi fondata sulla mobilità dell'immagine. Le qualità primarie del linguaggio non sono riconoscibilità, leggibilità e univocità del segno ma i valori espressivi di messa in scena, spettacolarità ed enfasi emotiva. In queste forme brevi di comunicazione assume un ruolo rilevante la durata temporale e l'integrazione audio-video. L'apporto audio definisce un insieme multi- 
dimensionale, costituito da altezza, intensità, durata, timbro, non considerati come parametri del suono ma come sensazioni e percezioni relative all'ascolto. Il dato sonoro entra in stretto rapporto con il materiale visivo a cui si riferisce, restituendo qualità che evocano eventi. In tal senso, la dimensione temporale svolge un ruolo fondamentale poiché l'incidenza non è solo tempo rappresentato ma tempo di comunicazione, che attribuisce senso alla nar-

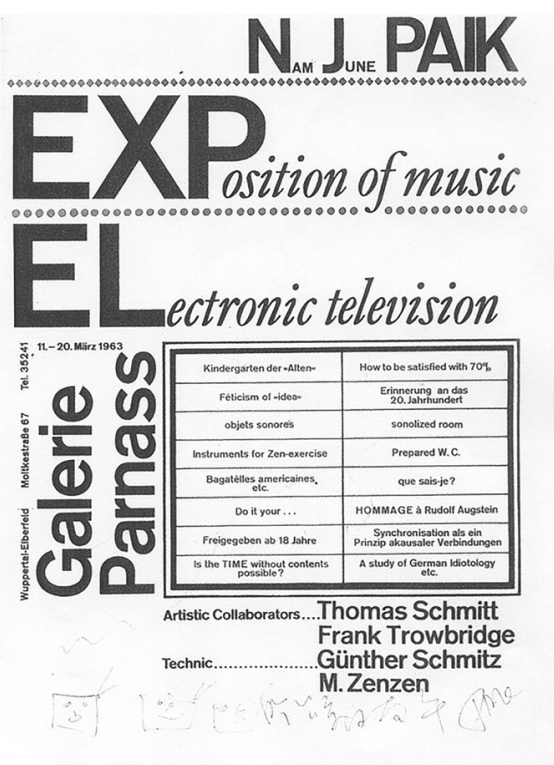

razione [Bettetini 1979]. II rapporto fra racconto iconico (gli spazi autonomi di discorso, la successione delle immagini e degli elementi grafici, la consistenza delle azioni) e le tecniche di scrittura elettronica (rallentate, accelerate, prive di coerenza spazio-temporale) restituiscono la narrazione come progetto integrato di forme plurime di rappresentazione. (O.Z.).

Fig. 6. Paik June Nam realizza la prima esposizione di videoarte nel 1963 a Wuppertal.
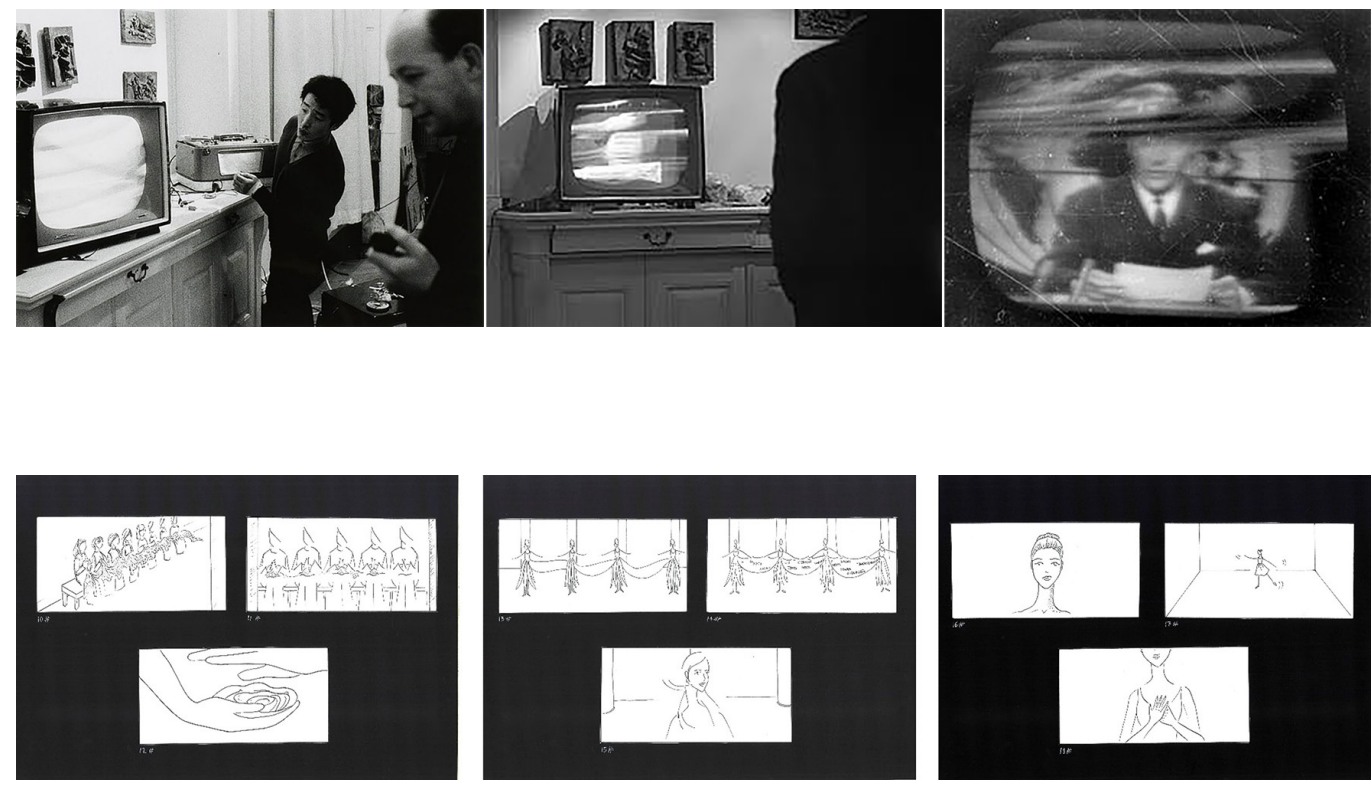


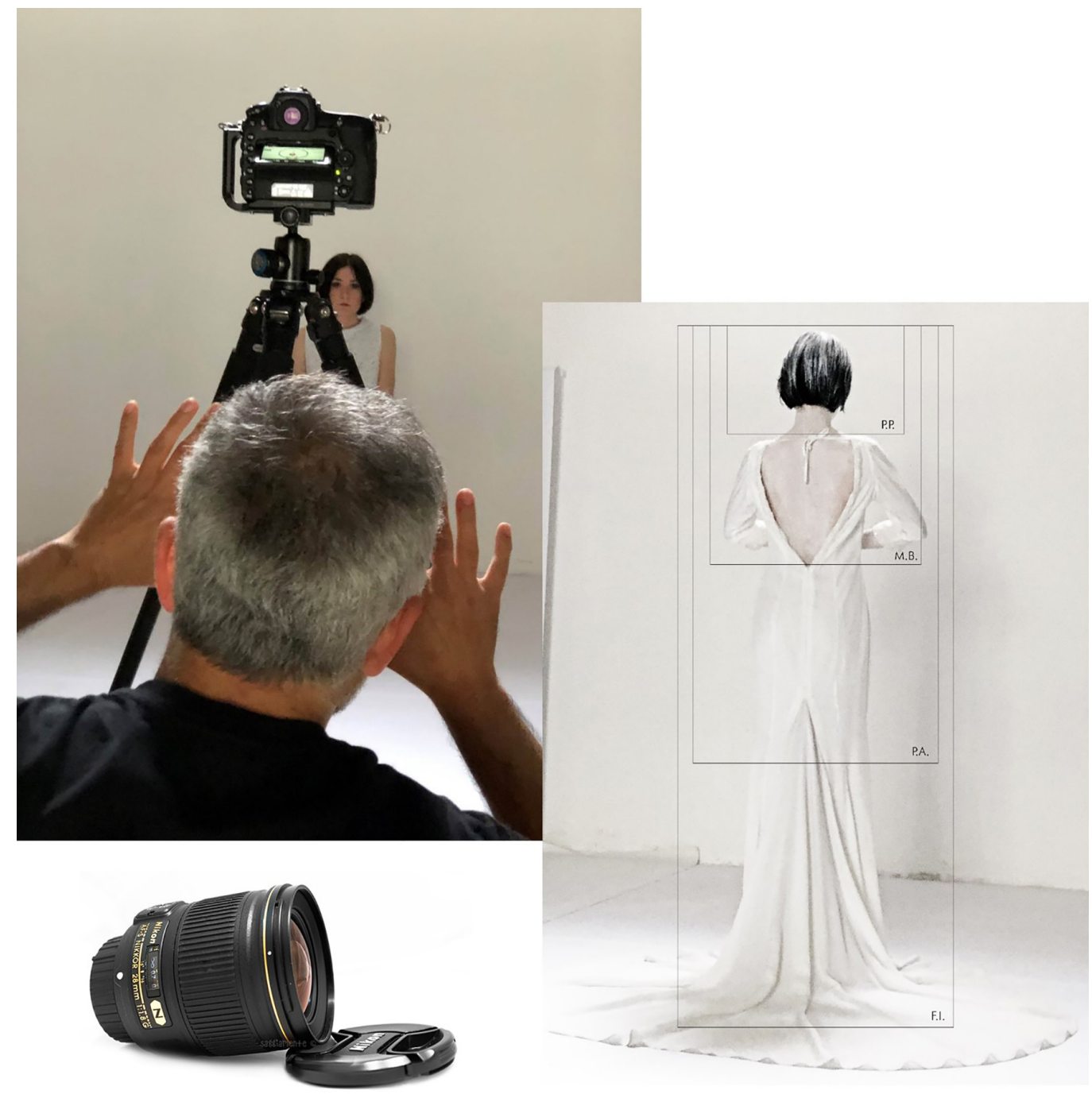

Fig. 9. FILIng: frames tratti dal videoclip e riprese

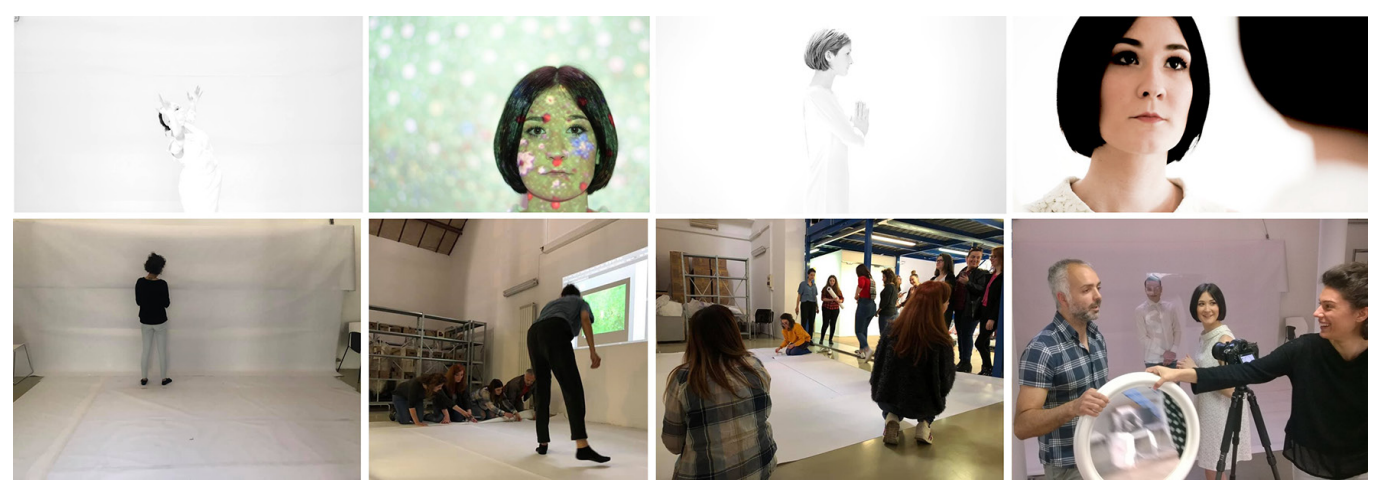




\section{FILIng_fili infiniti nella diversità di genere}

|| 27 febbraio 2019, II fiume di rose e II gesto sacro entrano in aula al Corso di Laurea magistrale in Design per l'Innovazione e diventano occasione di riflessione critico-progettuale per promuovere un laboratorio didattico-formativo e raccontare attraverso un videoclip una storia nuova sulle questioni di genere. Oltre ai due riferimenti succitati, contribuiscono alla costruzione del messaggio le posizioni del noto psichiatra Vittorino Andreoli (1940) che, nelle sue recenti pubblicazioni e interviste, analizza i cambiamenti sociali nel rapporto uomo-donna, affermando: "la donna è andata avanti tantissimo. II dramma è che gli uomini sono rimasti omuncoli. Oggi però, la donna non deve fare l'errore del femminismo degli anni '70. Escludere gli uomini. Se si vuole cambiare, bisogna farlo insieme. Altrimenti l'uomo resterà culturalmente distaccato. Resterà un omuncolo" [Piccinni 20।8].

Su queste suggestioni e acquisizioni di consapevolezza nonché di analisi delle tendenze stilistiche sulla base di una campionatura di cortometraggi esaminata si è costruita la trama del videoclip, articolata attorno all'immagine iniziale di una donna che contempla il quadro PrimaVera della serie pittorica BellaMBriana di Rita Esposito [Esposito 2016]. Concepito come una trasposizione in immagini del mondo interiore della donna e sulla riflessione di sorellanza, accoglienza e condivisione, il video ha assunto un carattere astratto e iconico e un linguaggio visionario. La trama è stata suddivisa in nove scene diverse, che hanno attribuito qualità emozionale ad ambienti e personaggi. II disegno di ogni scena (storyboard) ha restituito fluidità alla storia (fig. 7) e permesso a lgor Todisco (art director) di stimare le riprese fotografiche definendo macchina da presa, formato del video, ottiche, luce, inquadrature, tempi e ritmi (fig. 8). Le scene sono state girate mute perché volutamente prive di dialoghi. Di fondamentale importanza è stata la ricerca e l'accordo con uno sfondo sonico, Epic Inspiring Cinematic Piano di ANtarcticbreeze, in grado di amplificare il contesto visuale delle scene, restituire un'atmosfera onirica e coinvolgere lo spettatore con una melodia incalzante, accenti forti e momenti di suspence. I luoghi delle riprese sono analogici e virtuali. Un'aula universitaria (tappezzata con fondale bianco) è stata trasformata in set cinematografico (fig. 9). Qui sono state girate la maggior parte delle scene mentre quelle ambientate nel chiostro dell'abazia di San Lorenzo ad Septimum (sede del Dipartimento) sono state realizzate in

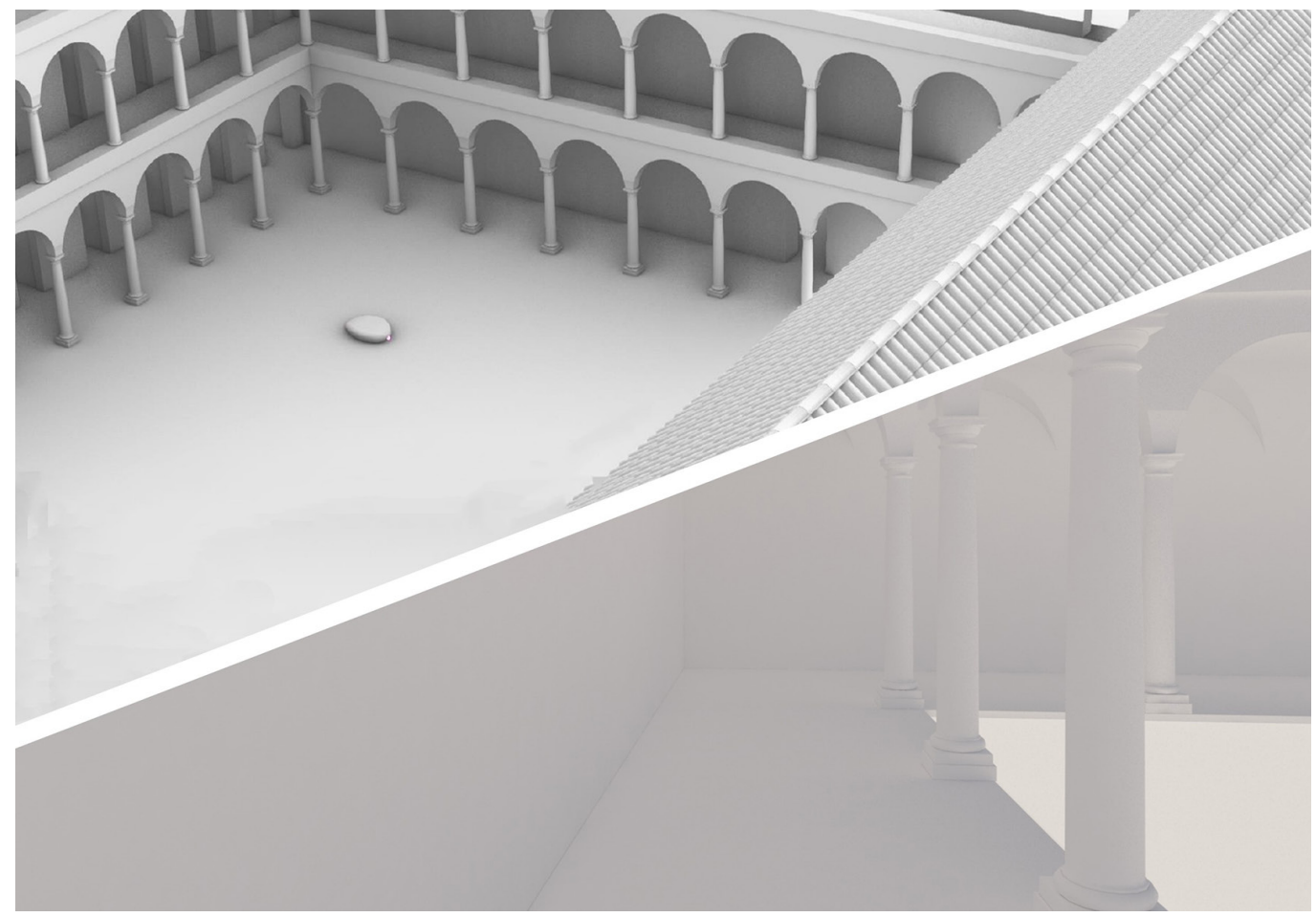



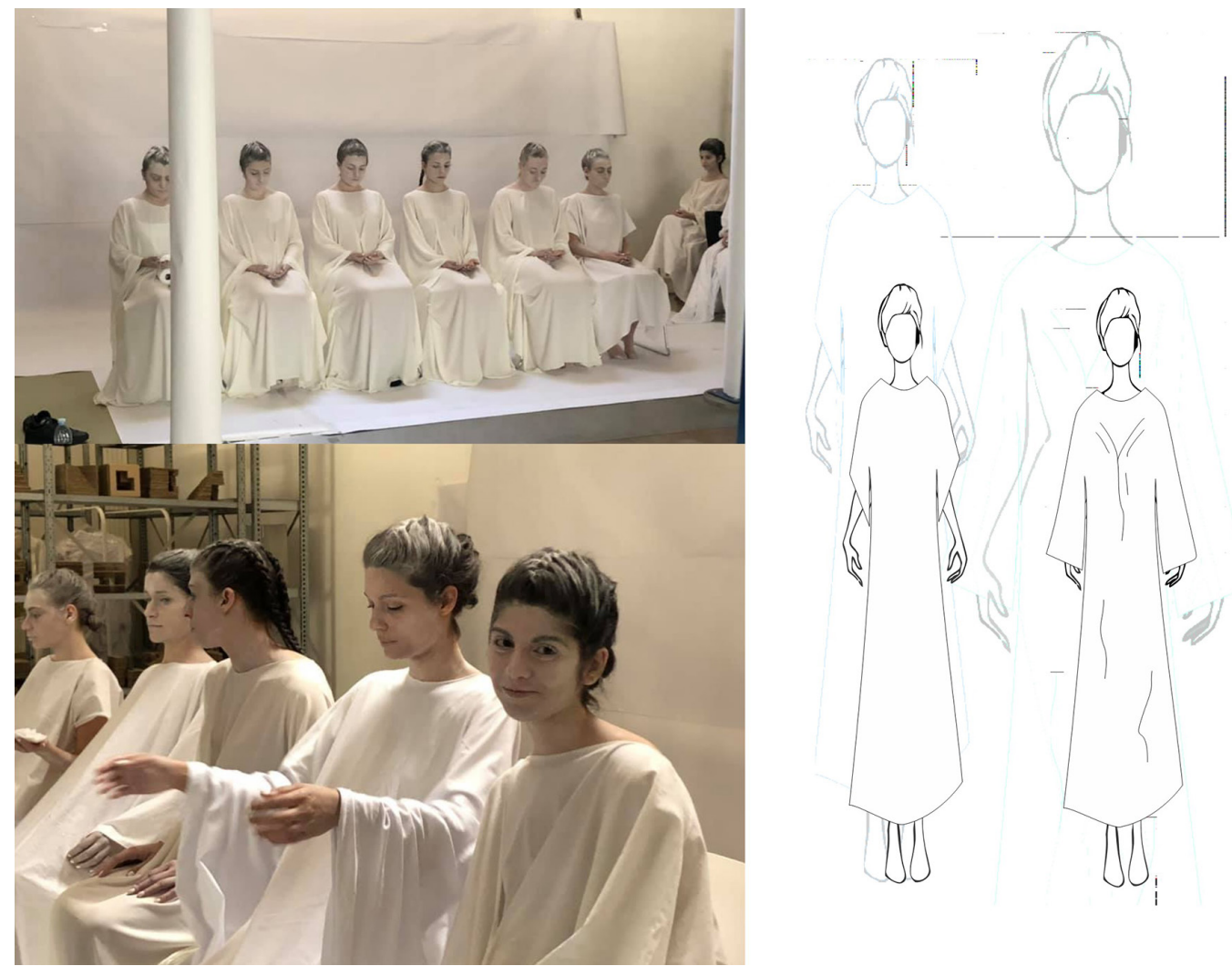

Fig. 12. FILIng: tipografia

cinetica, prove grafiche

e inserimento dei test
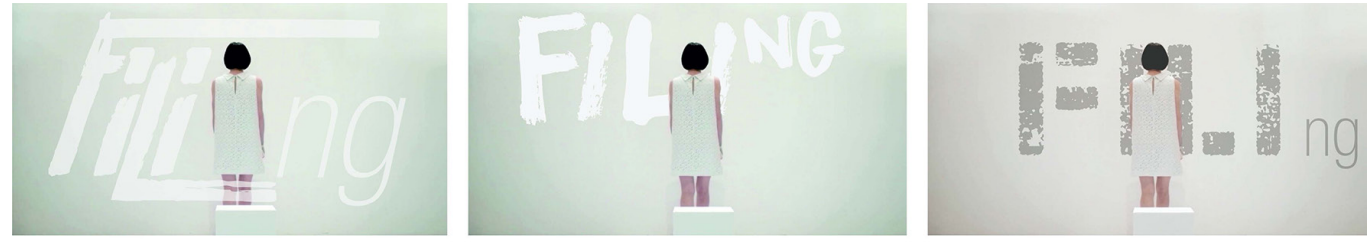

filing filing filing filing filing filing Ptling FILING thiNG titho

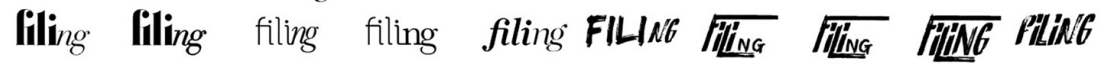

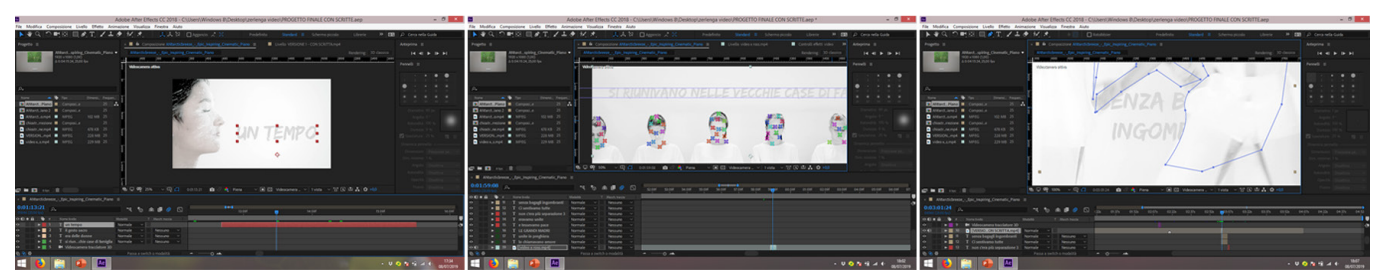


modellazione digitale (fig. I0). Nel rispetto di scene e ambientazioni sono stati pensati gli abiti dei personaggi, progettati con disegni a schizzo per la stesura di figurini d'illustrazione, poi definiti da disegni à-plàt (disegni tecnici) e cartamodelli per la messa in opera (fig. I I). In linea con l'immaginario onirico gli abiti sono stati realizzati in tessuti morbidi di colore bianco e dai tagli geometrici semplici. Solo l'abito della Grande Madre è stato impreziosito da rose di colore bianco, realizzate all'uncinetto. Analogamente, anche il trucco ha seguito due registri: bianco, per le scene oniriche, naturale, per le reali.

La gestione grafica dei testi è stata particolarmente ricercata per non impattare con il carattere fashion del videoclip e con la ricchezza degli elementi visuali presenti. I brani tratti da II gesto sacro sono stati agganciati al movimento delle scene ricorrendo alla tecnica della tipografia cinetica e, per non interferire con le immagini in movimento, i testi sono stati concepiti come epigrafi su muro già esistenti negli scenari di fondo e sono stati scritti con un carattere grafico dallo stile 'urban' (Edo SZ Regular) (fig. 12). Particolare cura è stata riposta nel progetto dei titoli di coda. Le fotografie dei volti delle/gli studentesse/i sono state affiancate in una sorta di dialogo visivo e sotto le immagini sono stati collocati i nomi per garantire leggibilità e durata dell'intero videoclip.

La post-produzione è stata una fase cruciale per il progetto video-grafico. Definite le scelte creative su scene, riprese, immagini, testi, audio e titoli di coda, il montaggio digitale ha tenuto conto della sincronizzazione di tutti gli elementi per restituire un prodotto grafico in cui ogni parte corrispondesse all'intero. Particolare cura tecnica è stata riposta nelle prove di leggibilità dei testi, bilanciamento dei toni, saturazione dei colori e luminosità delle scene così come nella gestione delle loro transizioni. II prodotto montato ha quindi restituito una visione emozionale ma anche una posizione concettuale sulla questione di genere. II titolo del videoclip, FILIng, nasce dalla fusione di 'fili' e feeling: 'fili', in italiano, come trame dell'antica arte dell'uncinetto e rinvio a una narrazione temporale;'feeling', come suono della parola inglese che indica la comunicazione di sensazioni ed emozioni, nata talvolta in modo del tutto spontaneo e immediato fra due o più persone. In sintesi, un videoclip, FlLIng, per connettere fili infiniti nella diversità di genere. (I.T., O.Z.).

\section{Conclusione}

Così concepito, il videoclip FILIng risponde sia a un'esigenza didattico-formativa nel campo del graphic design (e sua applicazione video-grafica), sia alla volontà (disciplinare ed etico-culturale) di connettere le questioni di genere attraverso i punti di vista del disegno nel rapporto dialettico fra immagine, forma grafica e identità visiva [Zerlenga 2007; Falcidieno 20 I0; Cicalò 20 I9]. In tal senso, le molteplici relazioni, che legano il disegno alle innumerevoli espressioni di arte e scienza, hanno annodato e tessuto 'fili' fra nuovi e rinnovati saperi per definire una visione della ricerca che, in modo trasversale, toccasse più impianti pluridisciplinari connessi alle scienze della rappresentazione. (I.T., O.Z.).

Fig. I 3. FILIng: Frame tratto dal videoclip: integrazione di modellazione 3D, rendering, tipografia
cinetica, fotografia.

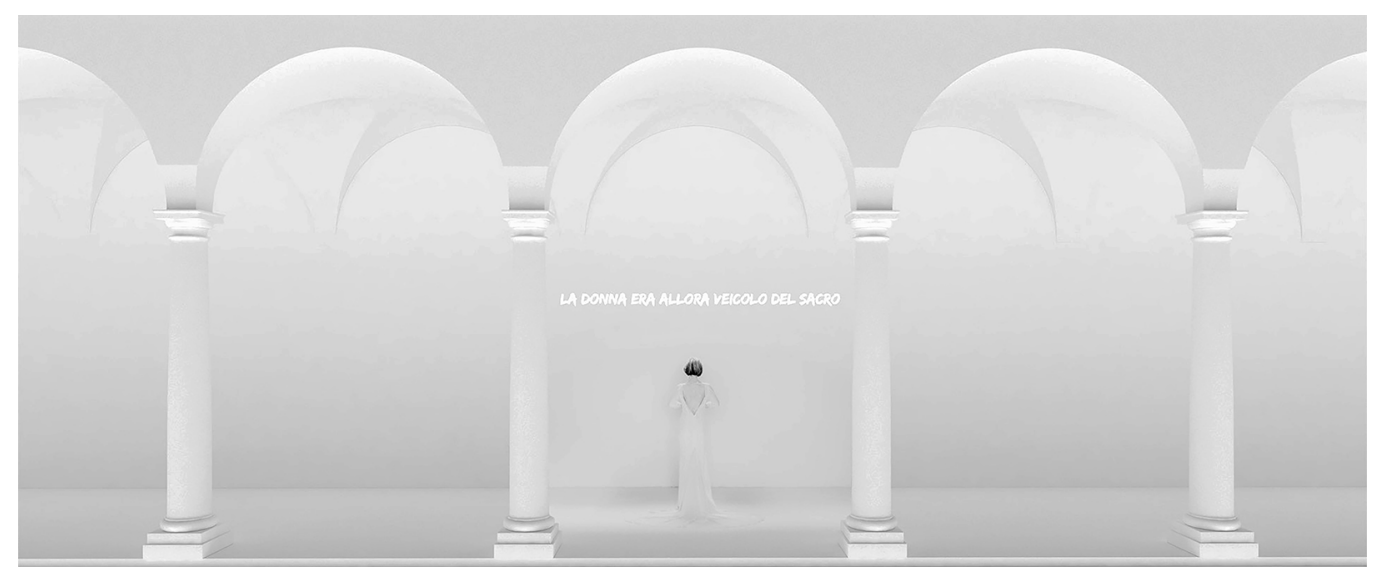




\section{Riferimenti bibliografici}

Arnheim Rudolf (198I). Arte e percezione visiva. Milano: Feltrinelli. (Ed. or. Arnheim Rudolph (1954). Art and visual perception: a psychology of the creative eye. Berkeley e Los Angeles: University of California Press).

Bernardelli Francesco (2003). Video art. In: Poli Francesco (a cura di). Arte contemporanea: le ricerche internazionali dalla fine degli anni '50 a oggi. Milano: Electa. pp. 274-320

Bettetini Gianfranco (1979). Tempo del senso: la logica temporale dei testi audiovisivi. Milano: Bompiani.

Busnelli Dino, Tibaldi Alessandro (a cura di). (20I I). Lev Manovich. Il linguaggio dei nuovi media. Milano: Olivares. (Ed. Or. Manovich Lev (200I). The Language of New Media. Cambridge: MIT Press).

Capone Franco (2017). La civiltà delle donne. In Focus.it, I ${ }^{\circ}$ marzo. <https://www.focus.it/comportamento/psicologia/la-civilta-delle-donne>.

Codino Fausto (a cura di). (2019). Friedrich Engels. L'origine della famiglia, della proprietà privata e dello Stato. Roma: Editori Riuniti.

Cicalò Enrico (2019). Graphic,Visual and Image Sciences. In: Luigini Alessandro, Panciroli Chiara (a cura di). IMG journal 0 I/20I9 Manifesto. pp. I06-I | 5. <http://www.img-network.it/issue-0|/>

Esposito Rita (2016). Rita Esposito. <http://www.ritaesposito.it/web/index.php>

Falcidieno Maria Linda (20 I0). Comunicazione-Rappresentazione. Testo, immagine, segno grafico. Firenze: Alinea.

Galbiati Marisa (2005). Movie Design. Scenari progettuali per il design della comunicazione audiovisiva e multimediale. Milano: Edizioni POLI.design

Gimbutas Marija (2008). Il Linguaggio della Dea. Roma:Venexia.

Göttner-Abendroth Heide (20।3). Le società matriarcali. Studi sulle culture indigene del mondo. Roma:Venexia.

Lischi Sandra (20 I5).Videoarte. In:Enciclopedia Italiana, IX,Appendice. <http://www.treccani.it/enciclopedia/videoarte_\%28Enciclopedia-Italiana\%29/>.

Piccinni Flavia (20|8). Intervista a Vittorino Andreoli. In: <https://www.vittorinoandreoli.it/interviste/I 72-vittorino-andreoli-siamo-la-societa-dell-homo-stupidus-stupidus-stupidus-oggi-solo-gli-imbecilli-possono-essere-felici.html>.

Percovich Luciana (2007). Oscure madri splendenti. Le radici del sacro e delle religioni. Roma:Venexia.

Ryan Paul (1988). A Genealogy of Video. In: Leonardo, vol. 2 I, n. I, pp. 39-44. Published by: The MIT Press. <https://www.jstor org/stable/| $5784 \mid 4>$

Schiavoni Giulio (a cura di). (1988). Johann Jacob Bachofen. II matriarcato. Ricerca sulla ginecocrazia del mondo antico nei suo aspetti religiosi e giuridici.Torino: Einaudi.

Stornaiuolo Marialuisa (a cura di). (20I5). Il culto alla Dea. Scritti di Momolina Marconi. Roma:Venexia.

Zerlenga Ornella (2007). Dalla grafica all'infografica. Nuove frontiere della rappresentazione nel progetto di prodotto e di comunicazione. Foggia: Claudio Grenzi Editore.

Autori

IgorTodisco, Imaging, mail@igortodisco.com

Ornella Zerlenga, Università degli Studi della Campania “Luigi Vanvitelli', ornella.zerlenga@unicampania.it

Per citare questo capitolo:Todisco Igor, Zerlenga Ornella (2020). Connessioni di genere ed esperienze di video-grafica/Gender connections and video-graphic experiences. In Arena A., Arena M., Brandolino R.G., Colistra D., Ginex G., Mediati D., Nucifora S., Raffa P. (a cura di). Connettere. Un disegno per annodare e tessere. Atti del $42^{\circ}$ Convegno Internazionale dei Docenti delle Discipline della Rappresentazione/Connecting. Drawing for weaving relationships. Proceedings of the 42th International Conference of Representation Disciplines Teachers. Milano: FrancoAngeli, pp. 847-866. 


\title{
Gender Connections and Video-Graphic Experiences
}

\author{
IgorTodisco \\ Ornella Zerlenga
}

Abstract

The proposed intervention concerns a didactic experience of video-graphic experimentation conducted in the more general topic of the science of representation. The contribution connects the disciplines of representation to contemporary multimedia languages of video graphics and explores the videoclips multidisciplinary system as short-term audio-visual communication.

Specifically, the experimental teaching experience (conducted within the master's degree course in Design per l'Innovazione, Department of Architecture and Industrial Design, University of Campania 'Luigi Vanvitelli') is to design of a short video, presented to the audience as a cultural event at the PAN, Palazzo delle Arti in Naples, in 2019 July. Inspired by the artistic contributions of Rita Esposito, II fiume di rose, and Chiara Tortorelli, II gesto sacro, the video-graphic project builds the narration of an emotional story that leads us to reflect on gender issues and, more generally, on diversity. Made with the artistic direction of the professional photographer lgor Todisco, the video lasts just over three minutes uses the languages and skills of graphic sciences, more generally letting the drawing to configure scenes, clothes and texts, interact with other forms of communication such as audio and dance.

Keywords

video-graphics, kinetic typography, digital modeling, drawing, graphic design.

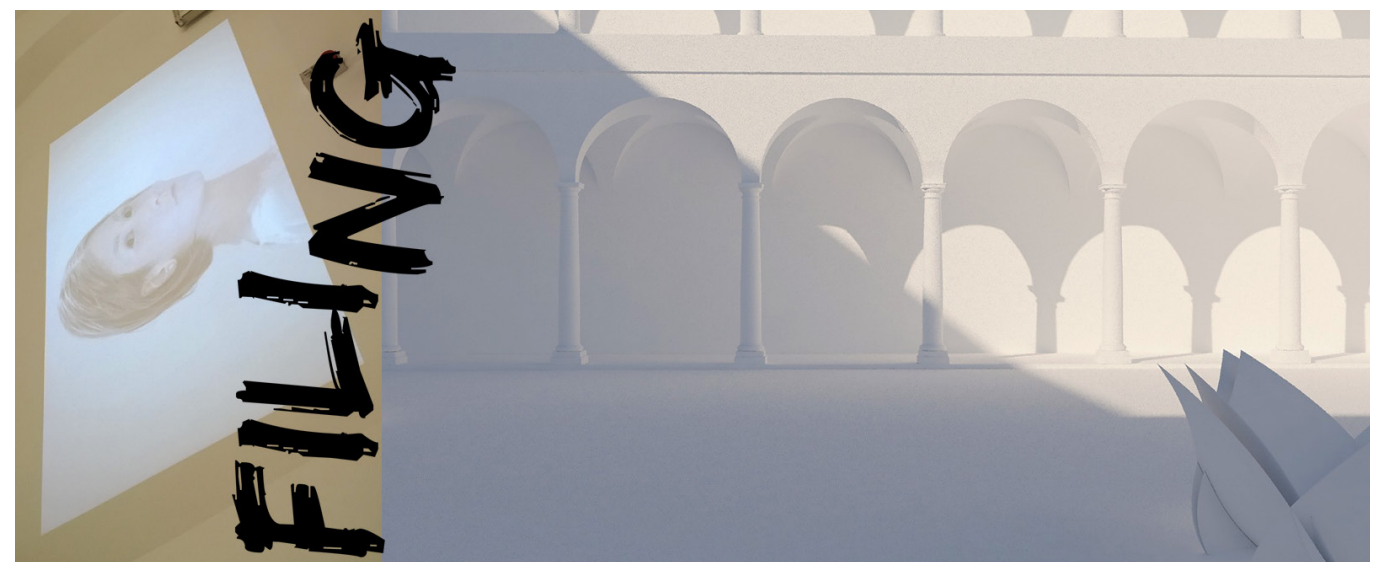




\section{Introduction}

Thinking on the relationships between drawing and innumerable forms of art and science, this contribution connects the disciplines of representation to contemporary multimedia languages of video graphics. Exploring the multidisciplinary system of the video clip as short-term audiovisual communication, the short film FILIng (coordinated by the writer and outcome of the teaching of the Master's Degree in Design for Innovation, Department of Architecture and Industrial Design, University of Campania 'Luigi Vanvitelli', 20 I 8-20 I9) proposes a narrative plot that, through infinite threads, connects multiple points of view on gender diversity, a theme still dramatically actual today, representing its foundational and cultural matrices. As emotional response, FILIng outlines an interweaving of meanings and defines a research vision that integrates drawing, multimedia and communication in a transversal way, knotting and weaving relationships between new and renewed knowledge. (O.Z.).

Fig. I. The artistic works II

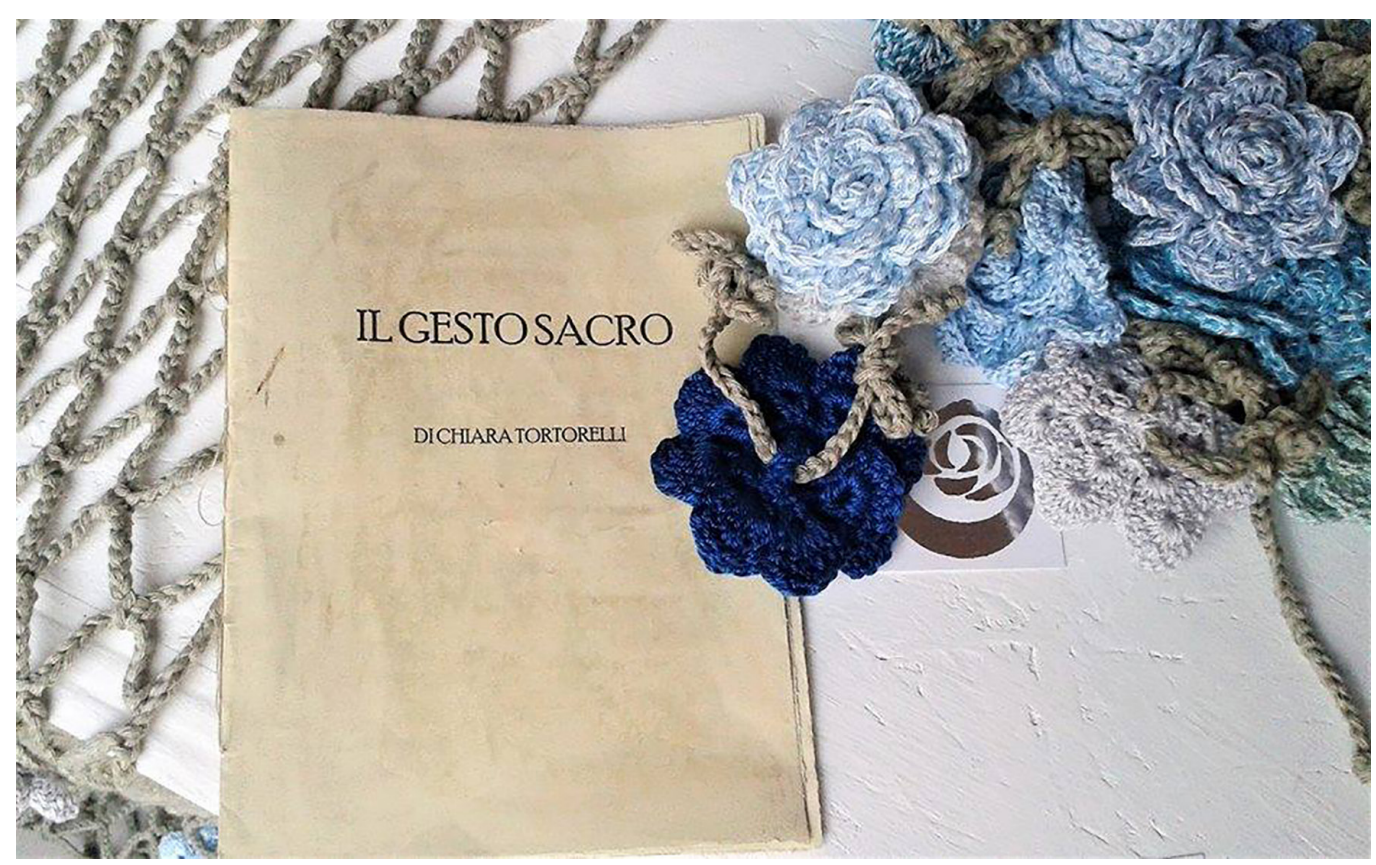

\section{Gender issues}

The artistic works of Rita Esposito (1968) and Chiara Tortorelli (1970) were of fundamental importance for the conception and narration of the message contained in the FlLIng video clip (fig. I). Il fiume di rose (roses river) was born from an original idea by Rita Esposito [Esposito 2016]. Presented to the audience in Naples on September 27, 2018, the work is a dynamic live-performance, a 9-month-long and 33-meter crocheted net. Celebrating the woman, the work recalls the concepts of sisterhood, hospitality and sharing. During the countless stages of live performance in all the country (fig. 2), the artist creates a collective artistic artifact formed by a network on which multiple hands of women, and then also of men, have knotted crochet roses of different colors. In its becoming, the work acquires an intense symbolic value by transforming a yarn into a place of creative thought and love. The work becomes architecture and a metaphor for life itself, evoking original sharing and solidarity, which find in the feminine epiphany a feeling of the world characterized by the network of affects and mutual care. The live performance ended at the PAN, Palazzo delle Arti (Palace of Arts) in Naples, on July 2I, 2019 where, for the occasion, the video clip FILIng was shown to the audience. 
The impromptu reading of the text II gesto sacro by Chiara Tortorelli, a short and engaging composition, accompanied the live performance by Rita Esposito. Born from childhood memories, the work recalls the silent activity of women weaving in a circle feeling united. Evoking places, traditions and sacred gestures, Tortorelli refers to the power of the Great Mother in weaving and connecting peace and harmony.

The cultural references of the artistic works refer to the ancient matriarchal societies where women had significant roles and the settlements were peaceful because the war was almost unknown. This civilization of women was egalitarian and believed in the Mother Goddess (fig. 3). Johann Jacob Bachofen (I8|5-|887) was the first to introduce in I86I the idea of a matriarchal past of humanity [Schiavoni 1988] as well as the philosopher and economist Friedrich Engels (1820-1895) in I884 explained its end because birth private property [Codino 2019]. World congresses on "Matriarchal studies" (Lussembrugo 2003, Texas 2005) and recent researches by Momolina Marconi (1912-2006) [Stornaiuolo 20 I5] and anthropologists Marija Gimbutas (1921-1994) [Gimbutas 2008] and Heide Göttner-Abendroth (I94I) [Göttner-Abendroth 20I3] demonstrate that the megalithic civilization of the Neolithic was centered on women and that this model did not correspond to the opposite domination of one sex over the other but to a culture of balance of roles. The economy was based on self-sustaining agriculture, on the gift culture instead of the exchange to ensure social rebalancing and, above all, on assembly-based participatory democracy and continuous search for consensus. The children lived in the maternal villages cared for by mothers and maternal relatives (women and men) and took the maternal name by inheriting the goods. Fatherhood was social, perhaps a legacy of male non-awareness in the fertilization process. According to Gimbutas, from 4,500 to 3,000 BC warrior peoples from the Volga and believers in male divinities swept across Europe and the Near East and slowly subjugated matriarchal societies with the physical strength and support of males of matriarchal populations. According to anthropologist Luciana Percovich (1947) [Percovich 2007], these claimed that women moved to their villages so that they could have paternity security and pass on the goods by male line. War became a form of economy and male force far more important than it once was. The women were segregated and submissive. The Mother Goddess became a distant memory, a social utopia so much so that in classical Greece Zeus surpassed Nature by giving birth from the head to the daughter Athena [Capone 20 I7] (fig. 4). (O.Z.).

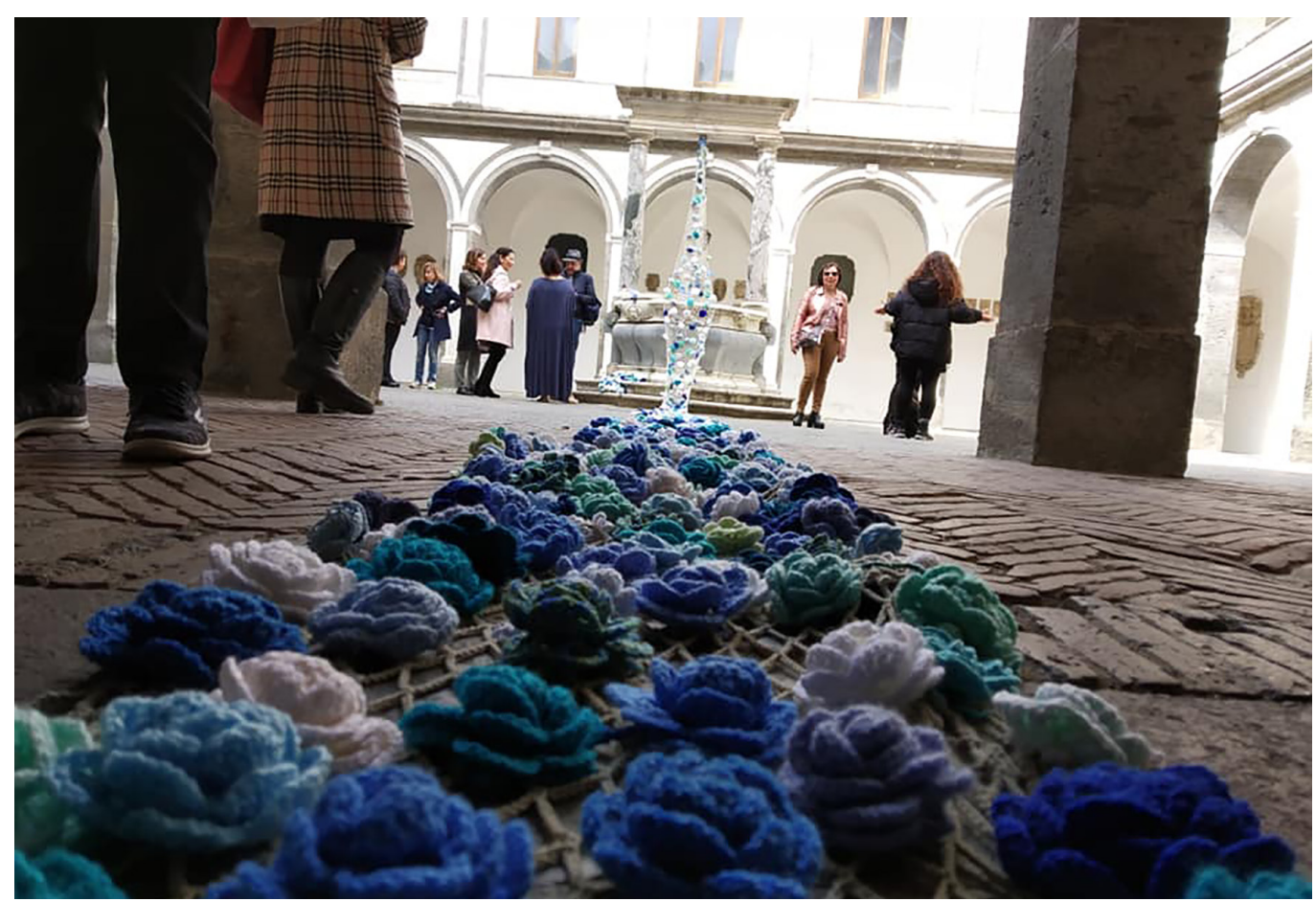


Fig. 3. Mother Goddess (Turkey, Ankara Museum)

Fig. 4. The birth of Athen from the head of Zeus (Attic black-figure kylix 550 BC, British Museum, London).
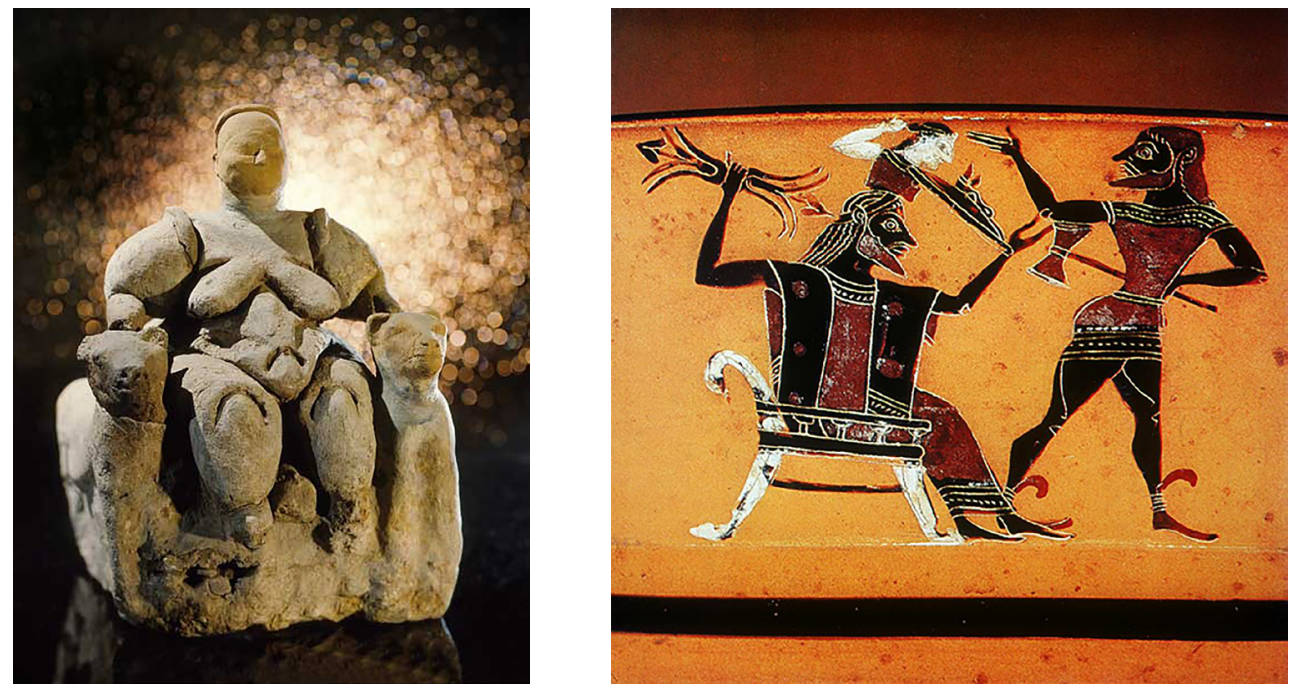

\section{Multiple forms of representation}

In 1963 the first video-art exhibition was held in Wuppertal in Germany [Lischi 20 I5]. Pioneer of this new form of communication was Paik June Nam (1932-2006). The exhibition, entitled Exposition of music electronic television, was set up in an apartment and Paik created a performance by mixing electronic music with numerous electronic images obtained by distorting television programs during the broadcast [Bernardelli 2003] (figs. 5, 6). Thanks to the subsequent recording and reproduction technologies of video-audio signals through magnetic tapes, videotapes introduced new communication opportunities on the market and in 1968 under the motto of VT is not TV the video artist Paul Ryan settled the technological and social difference between videotape and television [Ryan 1988]. This new technology had a strong impact in the artistic world. The dynamic dimension of the video outmatched static image and photography and, exploiting the communication potential of the television screen ('tele', from the Greek 'far'), settled the extraordinary ability to carry a dematerialized message everywhere.

Video projection became established on the scene as a new 'symbolic form' and from the end of the eighties of the last century the orientation of visual languages became increasingly multimedia. The integration of writing, sound, visual image and animation led to the creation of new products in the field of graphic design and a different way of looking at art. The invention of a new means of conveying the product (no longer the 'paper' but the 'video') integrated both the art of 'space' (drawing) and 'of time' (sound and animation) [Galbiati 2005]. These multimedia products made it possible to design narratives in which space and time connected according to an aesthetic of speed and discontinuous, interstitial, short logics. In the book The language of new media Lev Manovich (1960) featured a 'screen society' dominated by digital media in which multimedia communication played a fundamental role [Busnelli et al. $20 \mathrm{ll}$ ]. This transformation of language originated hybrid communication systems made up of flows of writings where static and moving images were mixed without discontinuity and time limits. The new era of the project characterized by dynamic images greatly involves the sense of vision, confirming Arnheim's thought: "Motion is the strongest visual appeal of attention" [Arnheim 1981, p. 303].

Graphics is part of this technological and cultural revolution in video art. The creative channel moves from paper to screen. The videographic is established as a synthetic image based on the changeability of the image. The primary qualities of language are not recognisability, legibility and uniqueness of the sign but the expressive values of staging, spectacularity and emotional emphasis. In these short forms of communication time duration and audio-video integration play an important role. The audio input defines a multidimensional whole, made 

exhibition entitled electronic television, 1963
Fig. 5. Poster for the

of height, intensity, duration, timbre, not considered as parameters of sound but as sensations and perceptions related to listening. The sound data come in close relationship with the visual material to which it refers, restoring qualities that evoke events. In this sense, the temporal dimension plays a fundamental role since the incidence is not only represented time but communication time, which gives meaning to the narrative [Bettetini 1979]. The

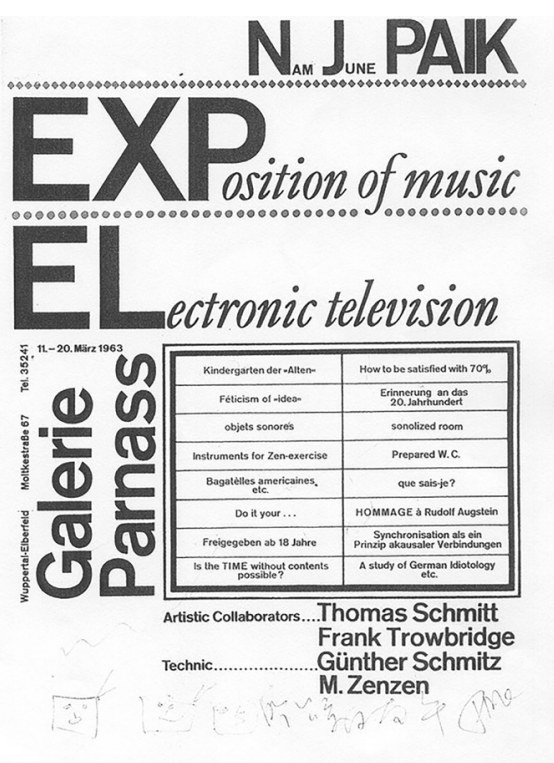

relationship between the iconic story (the autonomous spaces of speech, the succession of images and graphic elements, the consistency of the actions) and the electronic writing techniques (slowed down, accelerated, devoid of space-time coherence) return the narrative as an integrated project of multiple forms of representation. (O.Z.).
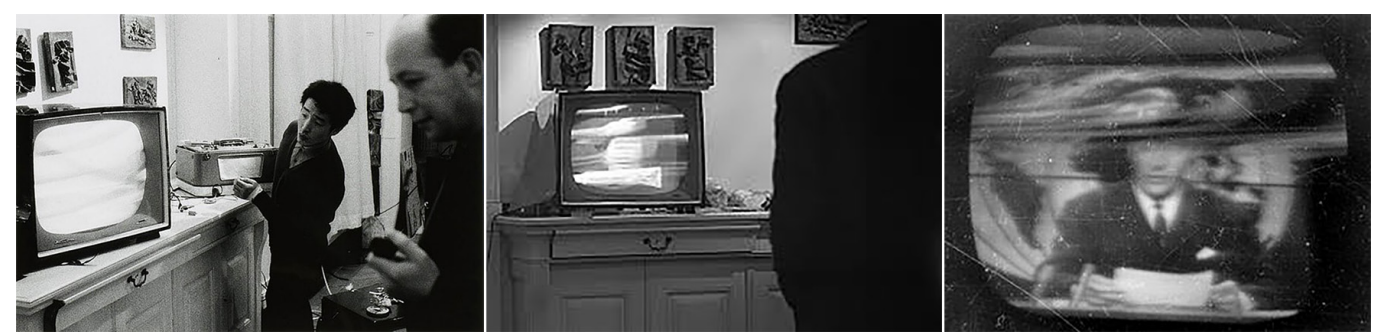

realizes the first video art exhibition in 1963 in Wuppertal.

Fig. 7. FlLIng: script and sketch drawing of the scenes.
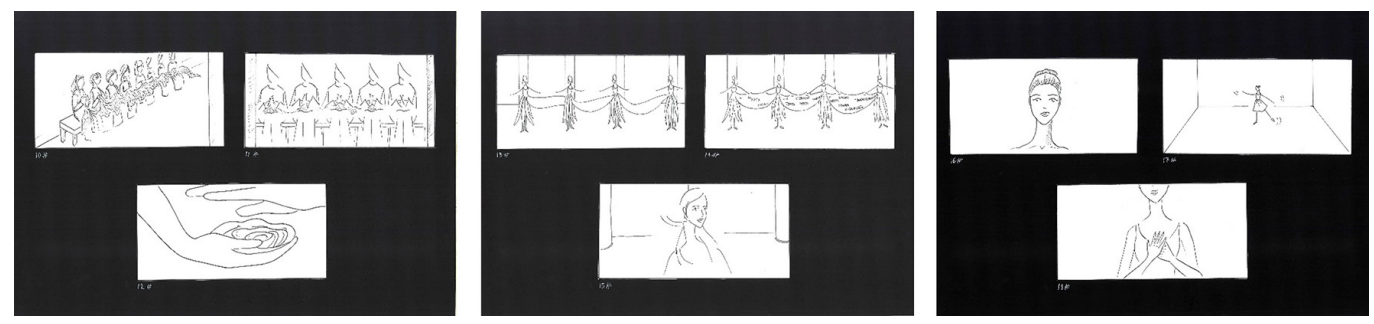


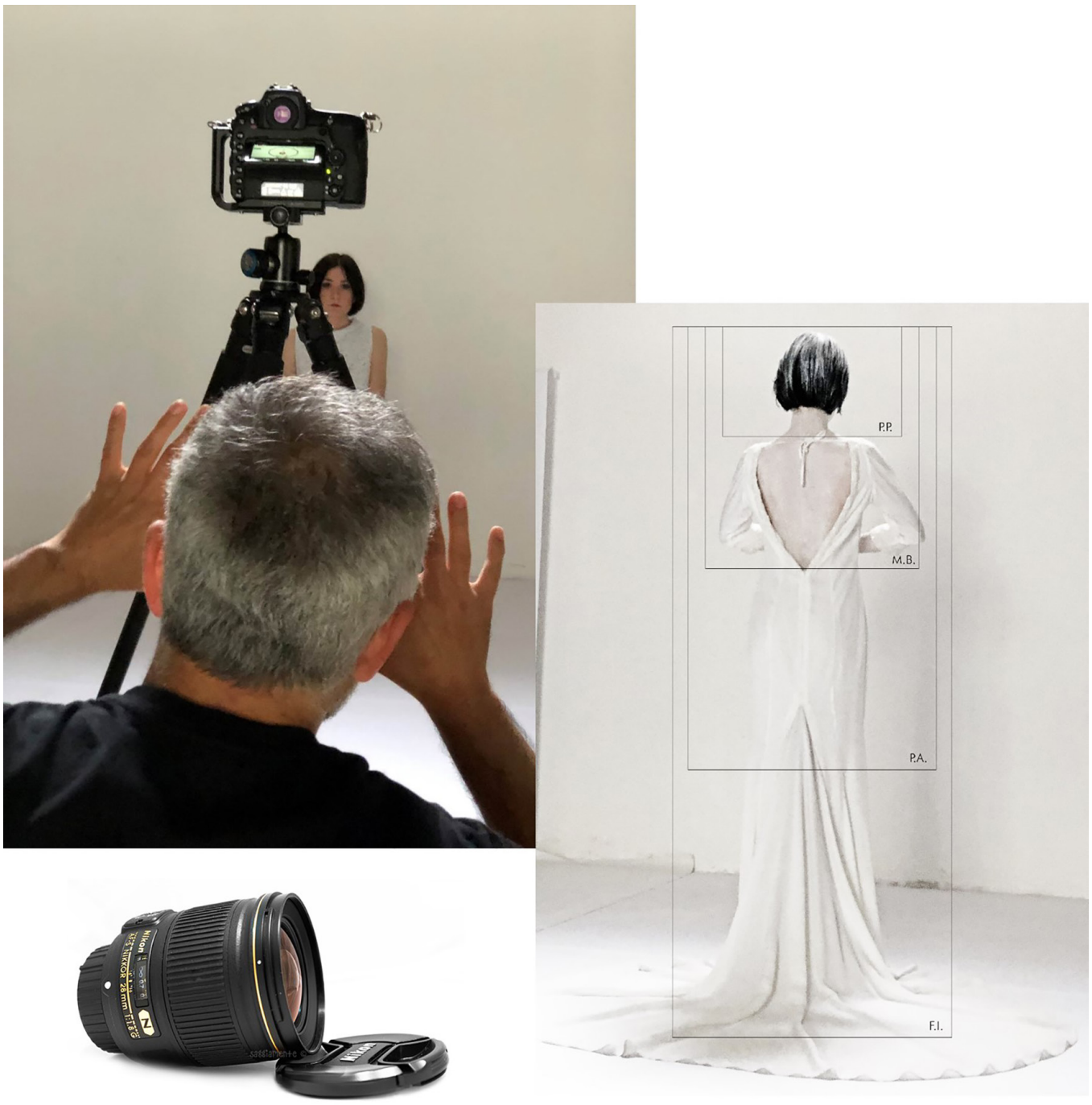

Fig. 9. FILIng: frames taken from video clips and
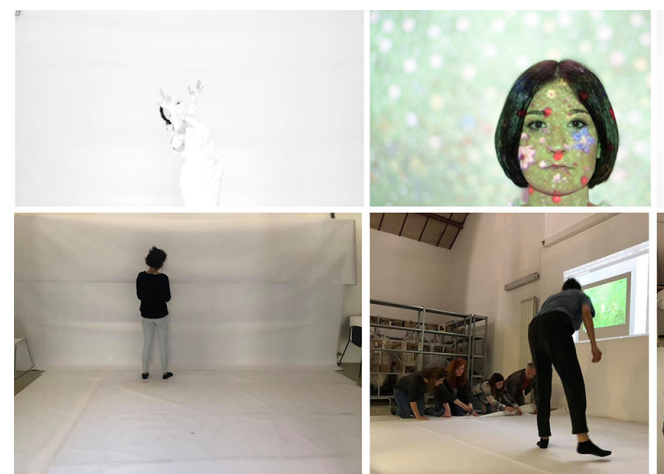

6
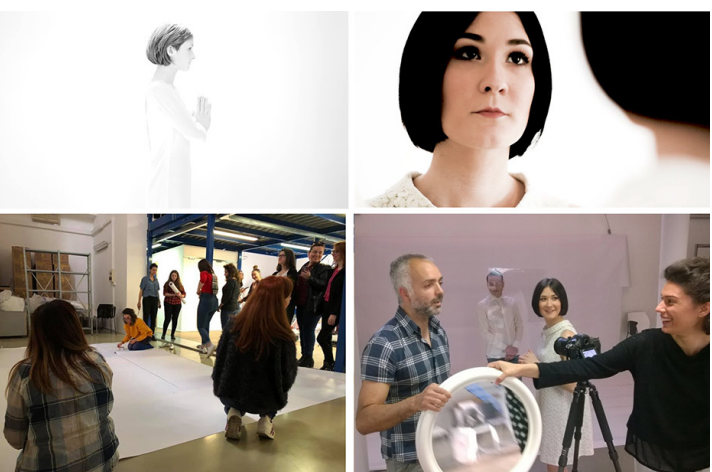


\section{FILIng_infinite 'fili' (threads) in gender diversity}

On February 27, 2019, II fiume di rose and II gesto sacro enter the classroom at the master's degree in Design per l'Innovazione and become an opportunity for critical-planning reflection to promote an educational-training laboratory and tell a new story through a video clip on gender issues. Over the two references mentioned above, the viewpoint of the popular psychiatrist Vittorino Andreoli (1940) contribute to the message construction. In his recent publications and interviews, he analyzes the social changes in the man-woman relationship, affirming: "the woman has gone on a lot. The drama is that men have remained homunculi. Today, however, women must not make the mistake of feminism in the 70s. Exclude men. If you want to change, you must do it together. Otherwise, man will remain culturally detached. A homunculus will remain" [Piccinni 20I8].

On these suggestions and acquisitions of awareness as well as analysis of stylistic trends based on a sampling of short films examined, the plot of the video clip was built, articulated around the initial image of a woman contemplating the PrimaVera picture of the BellaMBriana pictorial series by Rita Esposito [Esposito 20 I6]. Conceived as a transposition into images of the inner world of women and on the reflection of sisterhood, welcome and sharing, the video has taken on an abstract and iconic character and a visionary language. The plot was divided into nine different scenes, which attributed emotional quality to environments and characters. The design of each scene (storyboard) restored fluidity to the story (fig. 7) and allowed Igor Todisco (art director) to estimate the photographic shots by defining the camera, video format, optics, light, shots, times and rhythms (fig. 8). Scenes are silent because they were deliberately devoid of dialogue.Very important was the research and agreement with a sonic background, Epic Inspiring Cinematic Piano by ANtarcticbreeze, capable of amplifying the visual context of the scenes, restoring a dreamlike atmosphere and involving the viewer with a pressing melody, strong accents and moments of suspense. Locations are reals and virtuals. A university classroom (covered with white backdrop) has been transformed into a film set (fig. 9). Here most of the scenes were shot while those set in the cloister of the abbey of San Lorenzo ad Septimum (headquarters of the Department) were made in digital modeling (fig. I0). Video's costumes have been designed in respect of scenes and

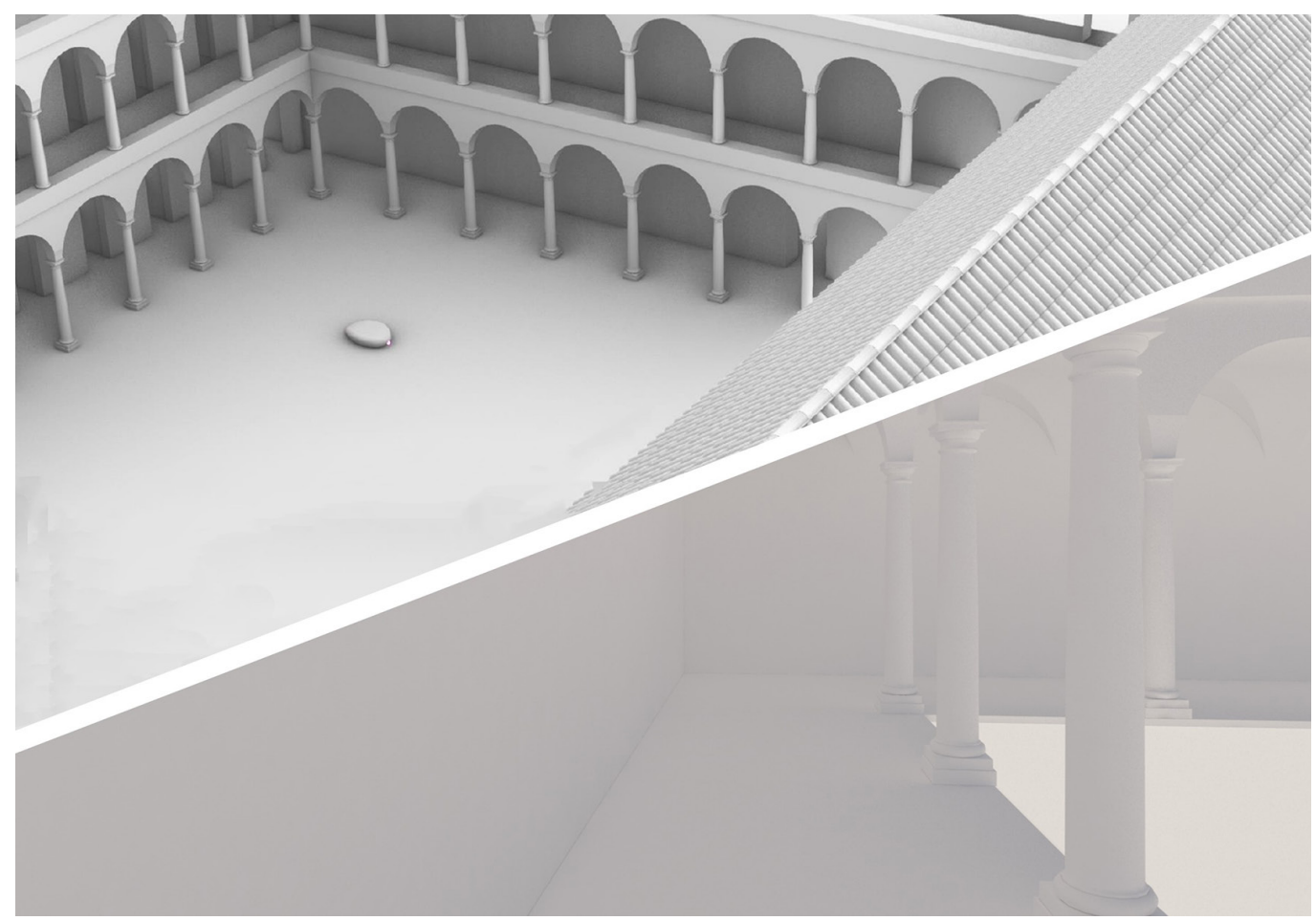



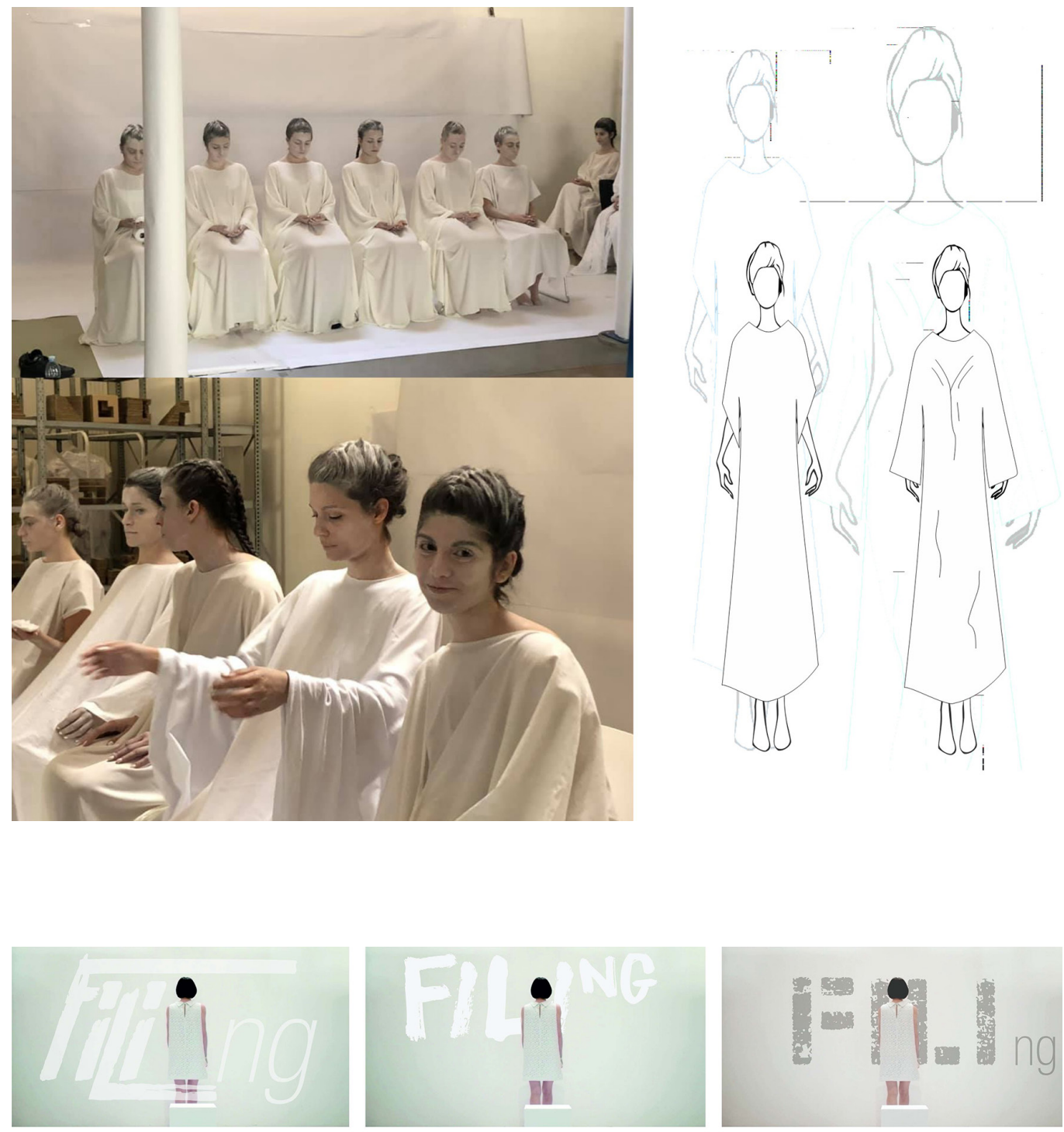

filing filing filing filing filing filing Ptling FILING thiNG titho

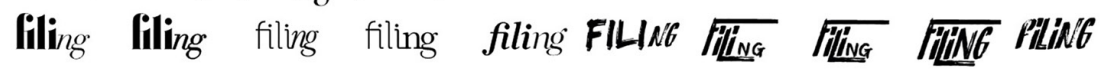

Fig. 12. FlLIng: kinetic

typography, graphic tests

and insertion of texts in

video footage.

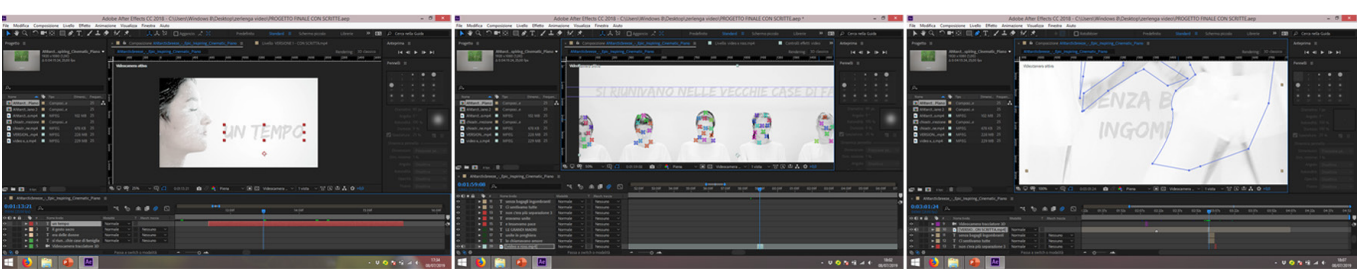


settings, made with sketch drawings for the drafting of sketches of illustration, then defined by à-plàt drawings (technical drawings) and patterns for the implementation (fig. I I). In line with the dreamlike imagery, the clothes were made of soft white fabrics with simple geometric cuts. Only the Great Mother's dress was embellished with white roses, crocheted. Similarly, makeup also followed two registers: white, for dreamlike scenes; natural, for the real. The graphic management of the texts has been particularly refined for not impact the fashion character of the video clip and the richness of the visual elements content. The passages from II gesto sacro have been linked to the motion of the scenes using the kinetic typography technique and, for not to interfere with the moving images, the texts have been conceived as epigraphs on the wall already existing in the background scenarios and have been written with a graphic character with an 'urban' style (Edo SZ Regular) (fig. I2). Special care has been taken in the closing credits project.The portraits of the students were placed side by side in a sort of visual dialogue and the names were placed under the images to ensure readability and duration of the entire video clip.

Post-production was a crucial phase for the video-graphic project. Having defined the creative choices on scenes, shots, images, texts, audio and end credits, the digital editing considered the synchronization of all the elements to return a graphic product in which each part corresponded to the whole. Technical detailed care has been used in the readability test of the tests, balance of tones, saturation of colors and brightness of the scenes as well as in the management of their transitions. The assembled product therefore returned an emotional vision but also a conceptual position on the gender issue. The title of the video clip, FlLIng, was born from the fusion of 'fili' (threads) and feeling: 'fili', in Italian, as plots of the ancient art of crochet and reference to a temporal narrative; 'Feeling', as the sound of the English word that indicates the communication of sensations and emotions, sometimes born in a completely spontaneous and immediate way between two or more people. In summary, a video clip, FILIng, to connect infinite threads in gender diversity. (I.T., O.Z.).

\section{Conclusion}

Thus conceived, the video clip FILIng responds both to an educational-training need in the field of graphic design (and its video-graphic application), and to the will (disciplinary and ethical-cultural) to connect gender issues through the points of view of drawing in the dialectical relationship between image, graphic form and visual identity [Zerlenga 2007; Falcidieno 20 10; Cicalò 2019]. In this sense, the multiple relationships, which link drawing to the innumerable expressions of art and science, have knotted and woven 'fili' (threads) between new and renewed knowledge to define a vision of research that, in a transversal way, touched multiple multidisciplinary systems connected to science of representation. (I.T., O.Z.).

Fig. 13. FILIng: Frame taken from the videoclip: integration of 3D modeling, rendering kinetic typography, photography.

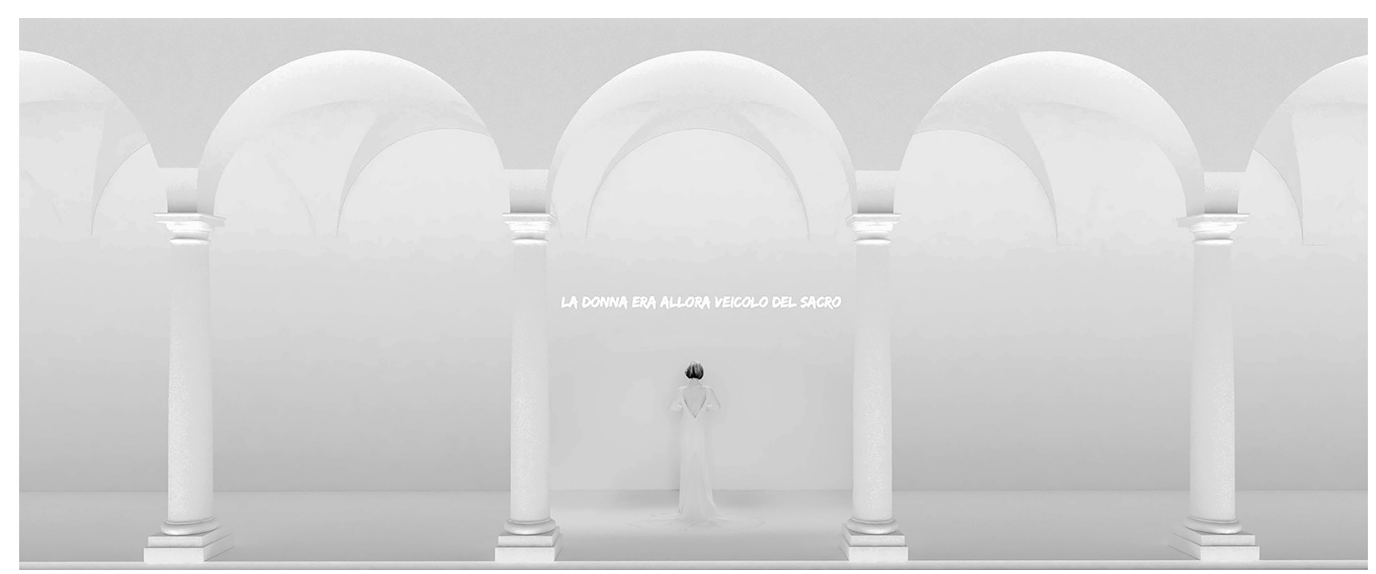




\section{References}

Arnheim Rudolf (198I). Arte e percezione visiva. Milano: Feltrinelli. (Ed. or. Arnheim Rudolph (1954). Art and visual perception: a psychology of the creative eye. Berkeley e Los Angeles: University of California Press).

Bernardelli Francesco (2003). Video art. In: Poli Francesco (a cura di). Arte contemporanea: le ricerche internazionali dalla fine degli anni '50 a oggi. Milano: Electa. pp. 274-320

Bettetini Gianfranco (1979). Tempo del senso: la logica temporale dei testi audiovisivi. Milano: Bompiani.

Busnelli Dino, Tibaldi Alessandro (a cura di). (20I I). Lev Manovich. Il linguaggio dei nuovi media. Milano: Olivares. (Ed. Or. Manovich Lev (200I). The Language of New Media. Cambridge: MIT Press).

Capone Franco (2017). La civiltà delle donne. In Focus.it, I ${ }^{\circ}$ marzo. <https://www.focus.it/comportamento/psicologia/la-civilta-delle-donne>

Codino Fausto (a cura di). (2019). Friedrich Engels. L'origine della famiglia, della proprietà privata e dello Stato. Roma: Editori Riuniti.

Cicalò Enrico (2019). Graphic,Visual and Image Sciences. In: Luigini Alessandro, Panciroli Chiara (a cura di). IMG journal 0 I/20 I 9

Manifesto. pp. |06-| | 5. <http://www.img-network.it/issue-0 I/>

Esposito Rita (20|6). Rita Esposito. <http://www.ritaesposito.it/web/index.php>

Falcidieno Maria Linda (20 I0). Comunicazione-Rappresentazione. Testo, immagine, segno grafico. Firenze: Alinea.

Galbiati Marisa (2005). Movie Design. Scenari progettuali per il design della comunicazione audiovisiva e multimediale. Milano: Edizioni POLI.design.

Gimbutas Marija (2008). II Linguaggio della Dea. Roma:Venexia.

Göttner-Abendroth Heide (20 I3). Le società matriarcali. Studi sulle culture indigene del mondo. Roma:Venexia.

Lischi Sandra (20 I5).Videoarte. In:Enciclopedia Italiana, IX,Appendice. <http://www.treccani.it/enciclopedia/videoarte_\%28Enciclopedia-Italiana\%29/>

Piccinni Flavia (20|8). Intervista a Vittorino Andreoli. In: <https://www.vittorinoandreoli.it/interviste/ I 72-vittorino-andreoli-siamo-la-societa-dell-homo-stupidus-stupidus-stupidus-oggi-solo-gli-imbecilli-possono-essere-felici.html>.

Percovich Luciana (2007). Oscure madri splendenti. Le radici del sacro e delle religioni. Roma:Venexia.

Ryan Paul (1988). A Genealogy of Video. In: Leonardo, vol. 2 I, n. I, pp. 39-44. Published by:The MIT Press. <https://www.jstor. org/stable/| $5784 \mid 4>$

Schiavoni Giulio (a cura di). (1988). Johann Jacob Bachofen. II matriarcato. Ricerca sulla ginecocrazia del mondo antico nei suoi aspetti religiosi e giuridici. Torino: Einaudi.

Stornaiuolo Marialuisa (a cura di). (20 I5). Il culto alla Dea. Scritti di Momolina Marconi. Roma:Venexia.

Zerlenga Ornella (2007). Dalla grafica allinfografica. Nuove frontiere della rappresentazione nel progetto di prodotto e di comunicazione. Foggia: Claudio Grenzi Editore.

\section{Authors}

IgorTodisco, Imaging, mail@igortodisco.com

Ornella Zerlenga, Università degli Studi della Campania “'Luigi Vanvitelli', ornella.zerlenga@unicampania.it

To cite this chapter. Todisco Igor, Zerlenga Ornella (2020). Connessioni di genere ed esperienze di video-grafica/Gender connections and video-graphic experiences. In Arena A., Arena M., Brandolino R.G., Colistra D., Ginex G., Mediati D., Nucifora S., Raffa P. (a cura di). Connettere. Un disegno per annodare e tessere. Atti del $42^{\circ}$ Convegno Internazionale dei Docenti delle Discipline della Rappresentazione/Connecting. Drawing for weaving relationships. Proceedings of the 42th International Conference of Representation Disciplines Teachers. Milano: FrancoAngeli, pp. 847-866. 